UCRL-53449

This report was prepared as an ascount of work sponsored by an agency of the United States Government. Neither the United States Government nor any agency thereof, nor any of their emplcjees, makes any warranty, express or implied, or assumes any legal liability or responsibility for the accuracy, completeness, or usefulness of any information, apparatus, product, or process disclosed, or represents that its use would not infringe privately owned rights. Reference herein to any specific cummercial product, process, or service by trade name, trademark, manufacturer, or otherwise does not necessarily constitute or imply its endorsement, recommendation, or favoring by the Uniled States Government or any agency thereof. The views and opinions of authors expressed herein do not necessarily state or reflect those of the United States Government or any agency thereor.

UCRL -53449

DEQ4 005629

\title{
Containment Barrier Metals for High-Level Waste Packages in a Tuff Repository
}

E. W. Russell

R. D. McCright

W. C. O'Neal

Manuscript date: October 12, 1983

If has bsen ropucinced from the best. ovaikstis copy to permit the broadest possible availatihity.

\section{LAWRENCE LIVERMORE NATIONAL LABORATORY University of California - Livermore, California - 94550}




\section{Contents}

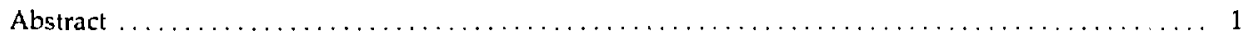

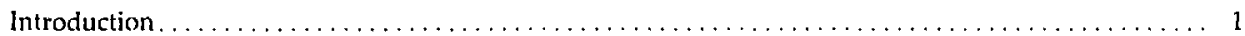

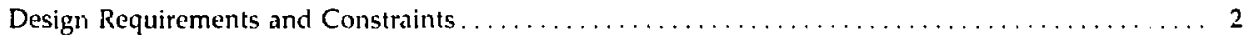

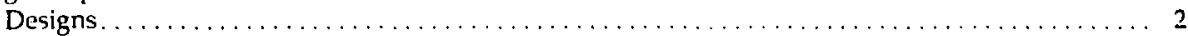

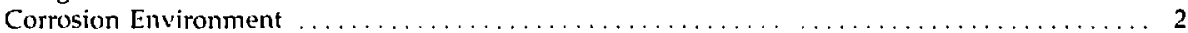

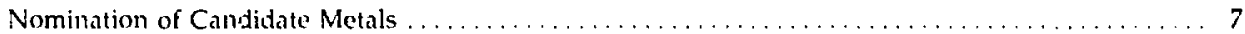

Iron-Base Allovs with a Ferritic Structure $\ldots \ldots \ldots \ldots \ldots \ldots \ldots \ldots \ldots \ldots \ldots \ldots \ldots \ldots \ldots$

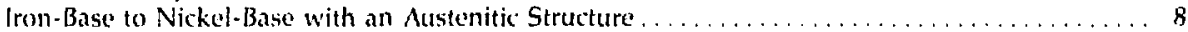

Copper, Titanium, and Zirconium-Base Alloys $\ldots \ldots \ldots \ldots \ldots \ldots \ldots \ldots \ldots \ldots \ldots \ldots \ldots \ldots \ldots$

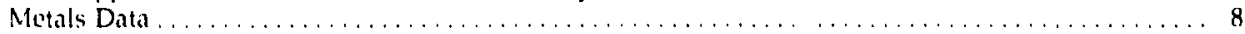

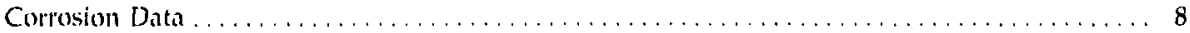

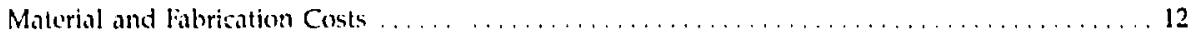

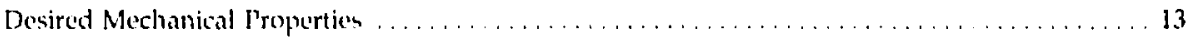

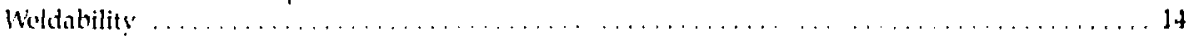

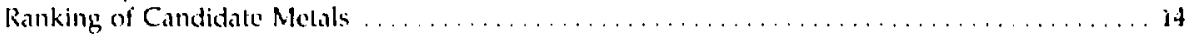

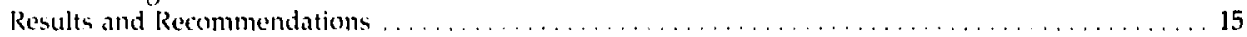

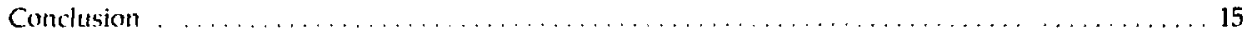

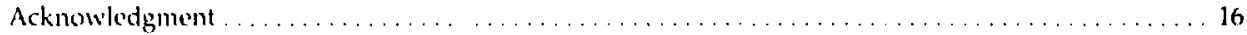

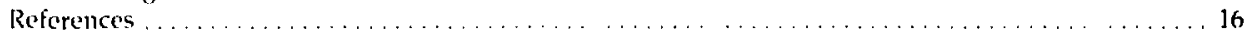

Appendix A-Emplacement Enviromment $\ldots \ldots \ldots \ldots \ldots \ldots \ldots \ldots \ldots \ldots \ldots \ldots \ldots \ldots \ldots \ldots \ldots$

Appendix B-Metal Components for Use as Canister

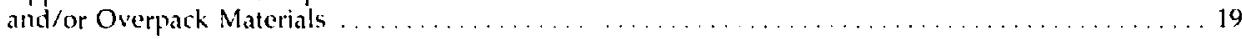

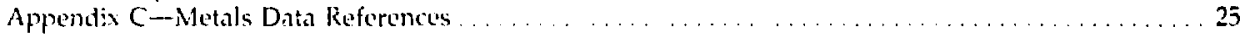




\title{
Containment Barrier Metals for High-Level \\ Waste Packages in a Tuff Repository
}

\begin{abstract}
The Nevada Nuclear Waste Storage Investigations (NNWSI) Waste Pachage project is part of the U.S. Department of Energy's Civilian Radioactive Waste Management (CRWM) Program. The NNWSI project is working towards the development of multibarriered packages for the disposal of spent fuel and high-level waste in tuff in the unsaturated zone at Yucca Mountain at the Nevada Test Site (NTS). The final engineered barrier system design may bo composed of a waste form, canister, overpack, borehole liner, packing, and the near field host rock, or some combination thereof. Lawrence Livermore National Laburatory's (LLNL) role is to design, model, and test the waste package subsystem for the tuff repository.

At the present stage of devclopment of the nuclear waste management program at LLNL, the detailed requirements for the waste package design are not yet firmly established. In spite of these uncertainties as to the detailed package requirements, we hav' begun the conceptual design stage. By conceptual design, we mean design based on our best assessment of present and future regulatory requirements We anticipate that changes will occur as the detailed requirements for waste package design are finalized.
\end{abstract}

\section{Introduction}

We have selected a few candidate metals for conceptual design of overpacks and canisters. Samples of these metals will be subjected to corrosion tests under repository conditions. Important materials-property data were developed to reflect engineering design requirements for potential candidate materials. The metals that were initially considered fall into the following categories: austenitic stainless steels, ferritic stainless steels, duplex stainless steels, high-nickel alloys, titanium alloys, zirconium ailoys, copper-nickel alloys, low-carbon steels, and cast irons. These metals are all commercially available.

Our procedure involved determining and evaluating the properties considered to be imiportant. These fall into four general categories:

- General and local corrosion resistance (including welded and heat-affected zones).

- Material and fabrication costs.

- Desired mechanical properties.

- Weldability.
This analysis ias resulted in the selection of four metals for canister and overpack materials, and one metal for horizontal borehole liners:

1. NISI 304L stainless steel.

2. AISI 321 stainless steel.

3. AISI 316L stainless steel.

t. Incoloy 825 nickel-base alloy.

5. AISI 1020 carbon steel (for horizontal borehole liners only).

Reference designs for defense high-level waste (DHLW), commercial high-level waste (CHLW), and spent fuel (SF) canisters have been selected from several LLNL conceptual designs. The reference designs may not necessarily be our preliminary or final design configurations, but we are focusing our attention on them during the conceptual design period. For the DHLW package, the AISI $304 \mathrm{~L}$ stainless steel pourcanister, which will be used to cast the glass at the waste reprocessing plant, has been selected for vertical emplacement into boreholes beneath 
the drift floors, and a similar but smaller pour canister has been selected for CHLW (see Figs. 1 and 2). For both boiling-water reactor (BWR) and pressurized-water reactor (PWR) spent fuel, the reference design is an AISI 304L stainless steel canister that will house consolidated fuel rods for vertical emplacement (see Fig. 3).

The reference canister and overpack metal is AISI 304L stainless steel, but alternative metals will also be considered for the following two reasons: (1) to provide a replacement material until the reference material is confirmed by testing uitder site specific conditions, and (2) to provide comparative data to support the choice of AlSI 304L stainless steel as the reference material during the regulatory review.

\section{Design Requirements and Constraints}

We are designing waste packages to meet the Final Rule, NRC IOClNR, Part 60), and derivative requirements. " To comply with these, we have developed the list of design reguirements given in Table 1. These requirements pertain to the disposal of defense high-level waste, commercial high-level waste, and spent fuel.

\section{Designs}

The waste package designs considered in the evaluation and selection of metals for canislers, overpacks, and liners are as follow's ${ }^{23}$ :

1.0) Reference designs emplaced in vertical borcholes with no liner and no packing.

1.1 DHI.W: emplacement of $61-\mathrm{cm}$ diam 3041. pour canister, 1-cm thick.

1.2 CHLW" implacement of $32-\mathrm{cm}$ diam $304 \mathrm{l}$ pour canister, $1-\mathrm{cm}$ thick.

13 Spent fuel: emplacement of consoliclated spent fuel rods in a $304 \mathrm{~L}$. canister, ]-cm thick.

These dimensions are assumed by LLNL at this time for conceptual design purposes only.

2.0 Alternative designs for vertical horeholes.

2.1 Alternative metals to $304 \mathrm{~L}$ for canisters and overpacks.

2.2 Overpacks for DHLW and CHLW for thcse canisters which do not meet acceptance criteria when rem ceived at the NNWSI repository.
2.3 Use of packing for spent fuel canistors, if the engineered system does not meet the release rate requirement.

3.0) Horizontal emplarement of waste packages within sted borehole liners.

Mecting the design requirements listed in Table $I$ involves determining and evaluating the engineering properties considered to be important. Lingineering properties are those physical characteristics (corrosion resistance, fracture toughness, weldability, cost, etc) which significantly affect the purformance of the canister and overpack functions in meeting the design requirements cost-effectively. Thus, the four general catrgories were estalilished:

- General and local corrosion resistance.

- Material and fabrication costs.

- Mechanical properties.

- Weldability.

Our desired values for candidate metals properties are summarized in Table 2. These values are meant to serve as general guidelines until detailed design requirements are firmly established.

\section{Corrosion Environment}

The waste package/repository environment will include high temperatures, water vapor, atmospher:c gases, condensed water containing chemical impurities, and radiation flux. A detailed description of the Topopah Spring unsaturated environment is given in Appendix A. The corrosion environment for the first 1000 years for which the metals were selected is summarized in Tables 3 and 6. 


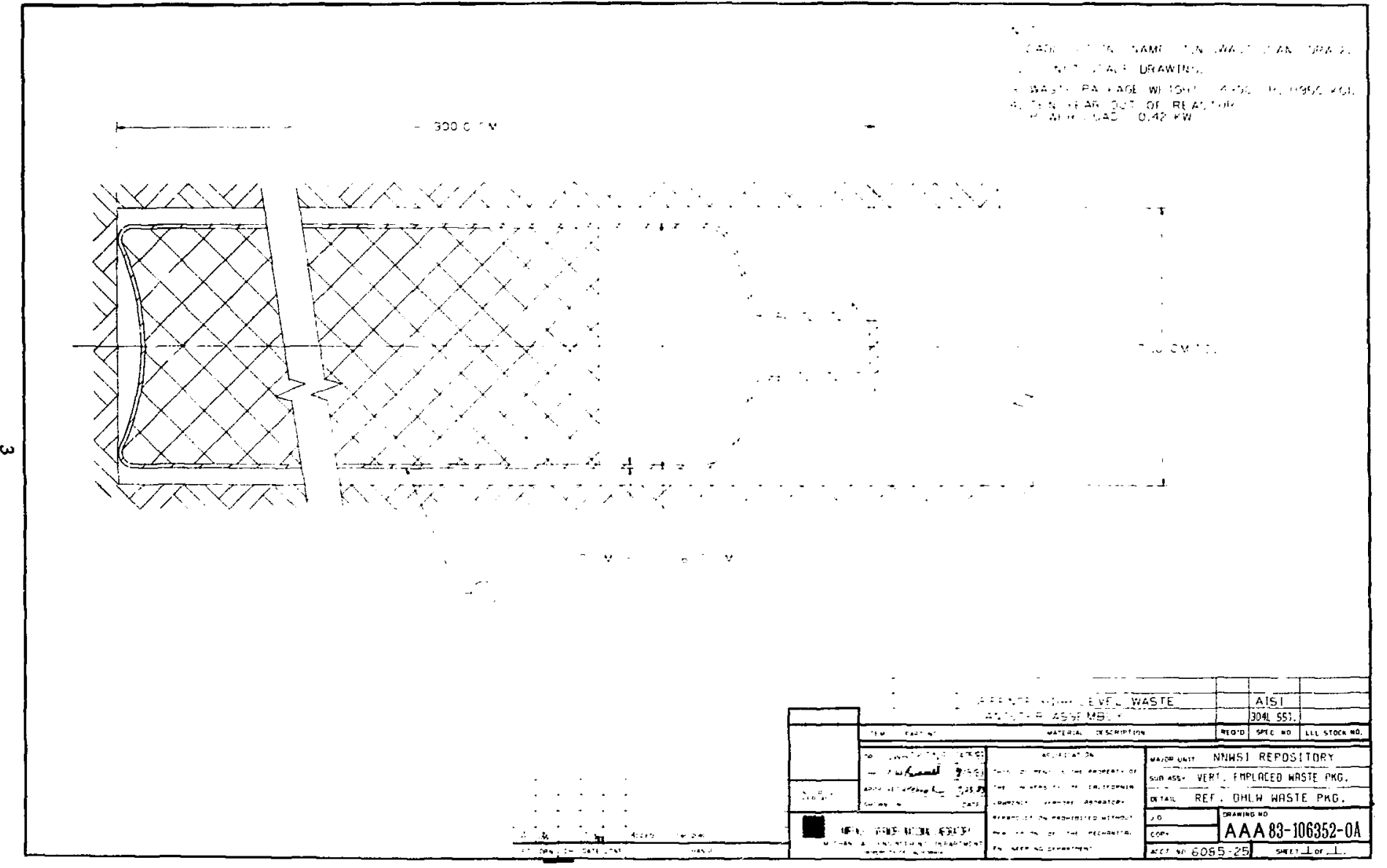

Figure 1. Peference waste package design for DHLW emplaced in vertical borehole. 


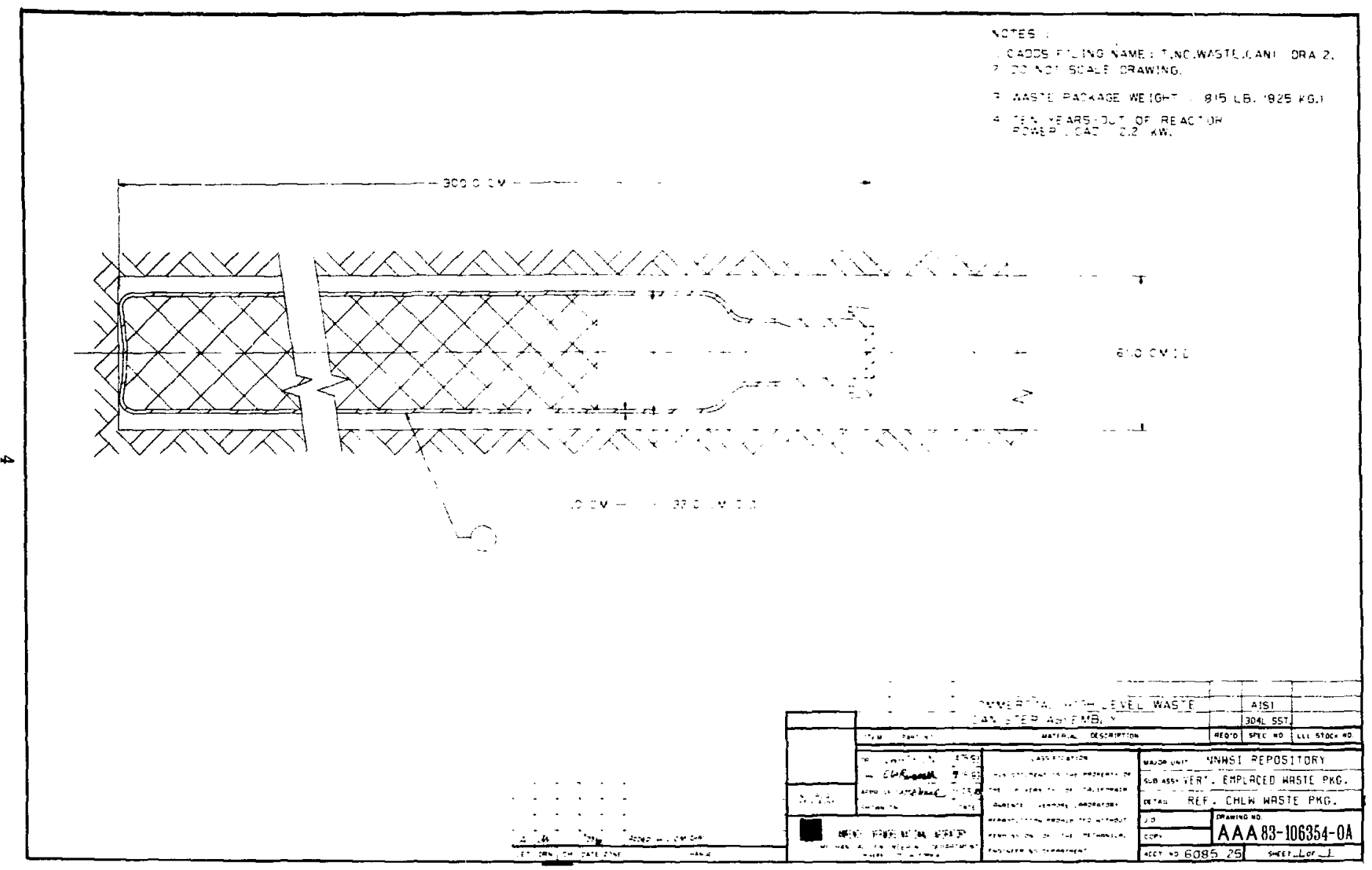

Figure 2. Reference waste package design for CHLW emplaced in vertical borehole. 


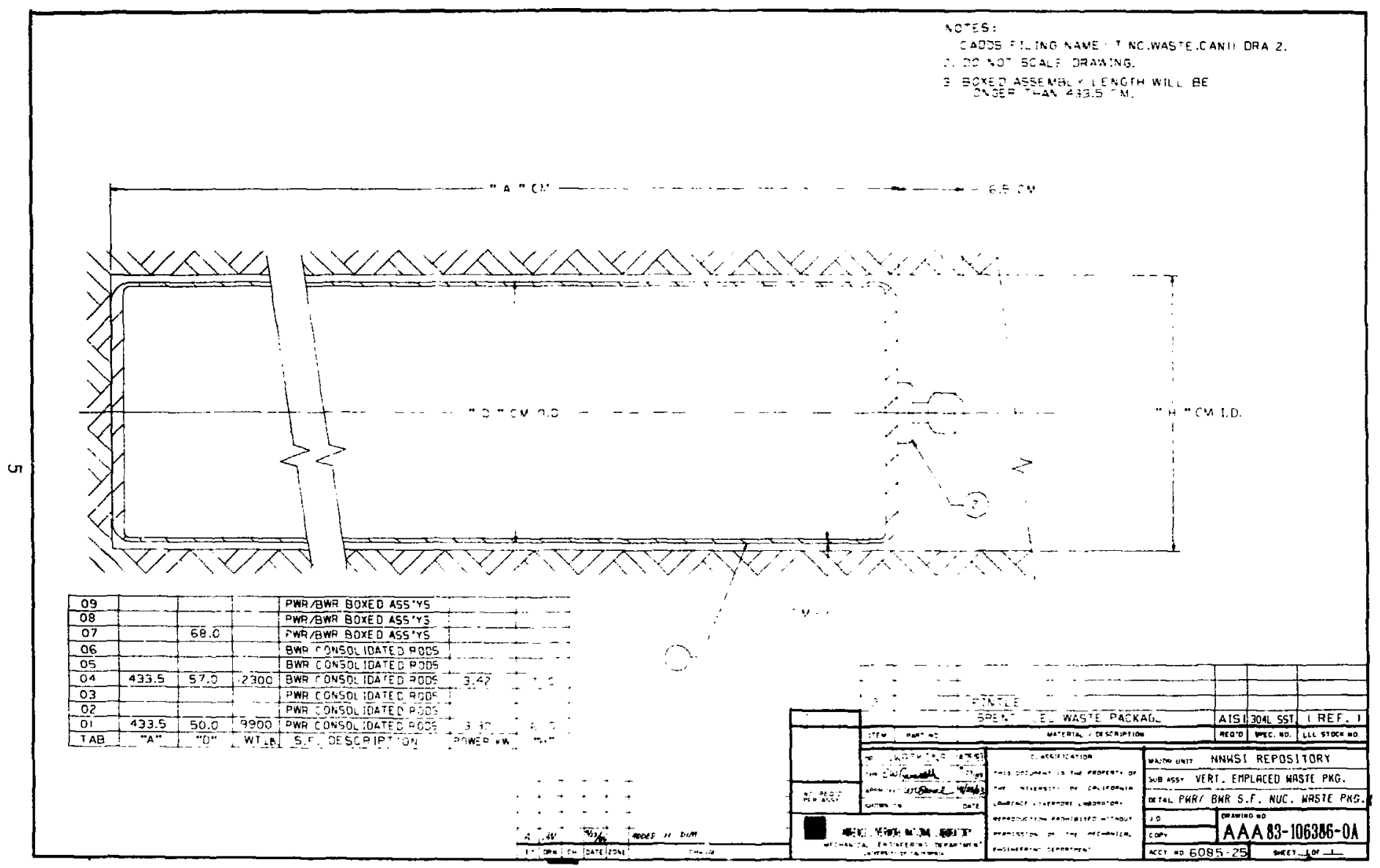

Figure 3. Reference waste package design for PWR and BWR spent fuel emplaced in vertical borehole. 
Table 1. LLNL design requirements derived from NRC 10 CFR 60.

Waste packages shall be designed to:

1. Contain the $n$ aste for 300 to 1000 years.

2. Maintain a release rate less than 10 " per year of radionuclide inventory present at the end of the containment period 1300 years minimum)."

3. We retrievable for 50 years alter smplacement of the first waste package."

4. Med nuclear criticality standards, i.e., not exceed an effective multiplication factor $\left(K_{\text {et }}\right)$ of 0.95

5. Not excerd lemperature limits of the waste forms, which are $773 \mathrm{~K}(500 \mathrm{C}$ for DIILW glass, $673 \mathrm{~K}$ 1400 C) for CH1.W Halass, and $623 \mathrm{~K}(350 \mathrm{C})$ for spent fuel cladding.

13. Not leak radioartive malerial in excebs ef applicable federal and state standards after a drop test of two times waste

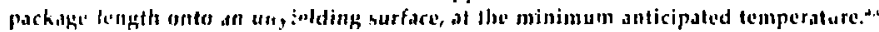

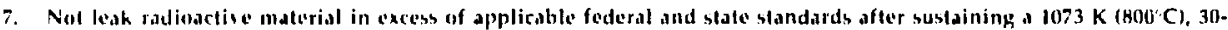
minutu fire test."

8. Nol Jish radiuaclive material in encens af applicable federal and state standards during or after transportation, liane dling, emplacentent, retrieval, and expected seismic londs. Further, these lisads must not compromise long-term performance."

4. Redain Legible, exlernally lalueded identification up to and including retrieval.

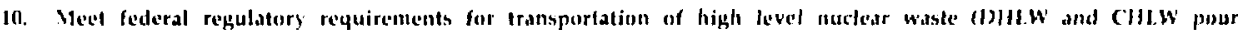
canisters)."

11. Meet requirements with considerations for cost-effoctiveness, including direct package costs and related repository system costs through the eperational periud."

"These requirements determine ar affect the selection of contuinment barrier melul.

'Interactions of waste package materials and hule-liner materials must not significantly increase the release rate of the waste forms or the corrosion rote of the containment barriters.

' With minimem ambient temperatures at Yucea Mountain on the order of 18 c and low waste form powernloads fos low as 50 (V), the outer skin temperature of the waste packages is assumed to be $16^{\prime \prime} \mathrm{C}$ minimum.

Table 2. Screening criteria for candidate metals.

\begin{tabular}{|c|c|}
\hline Attribute & Desired value \\
\hline Corrosion & $1 \operatorname{mil}(0.025+\max ) /$ year \\
\hline Yithd strength at $800^{\circ} \mathrm{C}$ & $\begin{array}{l}10,000 \text { psi (275.5 Ml'a) } \\
\min \end{array}$ \\
\hline Impact strength at $18^{\circ} \mathrm{C}$ & $\begin{array}{l}15 \mathrm{ft}-\mathrm{lb}(20 \mathrm{j}) \text { Charpy } \\
\text { v-notch, min }\end{array}$ \\
\hline Ductility at $18 \cup \mathrm{C}$ & $\begin{array}{l}25 \% \text { elongation, min } \\
\text { (annealed) }\end{array}$ \\
\hline Weldability & $\begin{array}{l}\text { As good as } 30+L \text { stain- } \\
\text { less steul }\end{array}$ \\
\hline Totsl cost (l-cm-thick plate) & $\$ 1 / \mathrm{in}^{3}\left(\$ 0.061 / \mathrm{cm}^{3}\right)$ \\
\hline
\end{tabular}

General and local corrosion data were obtained from the avilable literature and preliminary l.L.NI. corrosion tests. All important know'n corrosion mechanisms that each motal will be sulijected to in the Yucca Mountain repository enviromment were considered. These are: groneral and locaized corrosion; pitting, crevice, and intergranular corrosion; and stress-assisted corrosion. A detailed discussion of waste package containment harrier corrosion mechanisms is given in Appendix B.

Table 3. Calculated waste package corrosion environment during initial 1000-year period.

\begin{tabular}{|c|c|c|c|c|}
\hline \multirow[b]{2}{*}{ Waste package } & \multicolumn{3}{|c|}{$\begin{array}{l}\text { Duralion (years) } \\
\text { (based on overpack temperature) }\end{array}$} & \multirow{2}{*}{$\begin{array}{c}\text { Initial gamma } \\
\text { dose rate } \\
\text { (rem/ht) }\end{array}$} \\
\hline & $\begin{array}{c}\text { Steam/Air } \\
a_{\text {thl }}>100^{\circ} \mathrm{Cl}\end{array}$ & $\begin{array}{c}\text { Steam/Air" } \\
\left(t_{\operatorname{can}}>100^{\circ} \mathrm{C}\right)\end{array}$ & $\begin{array}{l}\text { Humid air/Water film } \\
\left(t_{c a n}<100^{\circ} \mathrm{C}\right)\end{array}$ & \\
\hline DHIW & 40 & 20 & 940 & $6.6 \times 10^{3}$ \\
\hline CHLW & 110 & 70 & 820 & $1.1 \times 10^{5}$ \\
\hline Spent fuel & 770 & 230 & 0 & $1.9 \times 10^{4}$ \\
\hline
\end{tabular}

andicates period when water drips on and flash evaporates from the canister.

b $\mathbf{b h}=$ borehole. 


\section{Nomination of Candidate Metals}

A list of 17 candidate metals which potentially will meet our design requirements is given in Table 4. These metal alloys are of three types:

- Iron-base alloys with a ferritic structure (numbers 1-4 in Table 4);

- Iron-base to nickel-base alloys with an austenitic structure (numbers 5-13); and

- Copper, titanium, and zirconium-base alloys (numbers 14-17).

The list of metals will be further screened later in this report to yield the five top contenders.

\section{Iron-Base Alloys with a Ferritic Structure}

The ferritic metals considered for this group are low-carbon steels, despite the face that lowcarbon steels may have a high corrosion rate in the anticipated oxidising environment of the repository: The redeeming properties of theso steels are: lowest overall unit cost; acceptable strength at room lemperature and $8 \mathrm{~b}) \mathrm{C} C$; and

Table 4. Candidate metals for canisters and overpacks.

\begin{tabular}{|c|c|c|c|}
\hline & $\begin{array}{l}\text { Commercial } \\
\text { material } \\
\text { designation }\end{array}$ & $\begin{array}{c}\text { ASTM unified } \\
\text { numbering } \\
\text { system }\end{array}$ & Chemical composition (wt'il \\
\hline 1. & AISI $1020 \mathrm{cs}$ & UNS G10200 & C.18-.23, Mn .3m.6, P .04 max, $5.05 \mathrm{mdx}$ \\
\hline 2. & ASTM1 A537H CS & - & $\begin{array}{l}\text { C.24 inax, Mn .7-1.35, P.035 max, S .04 max, Si .15-.5, C r .25 max, Ni .25 mux, Mn } \\
.08 \text { max, Cu .35 max }\end{array}$ \\
\hline 3. & AISI +119 ss & UNS $5+0900$ & 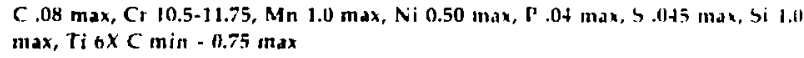 \\
\hline 4. & $26 \mathrm{Cr}-1 \mathrm{Moss}$ & UNS S44626 & 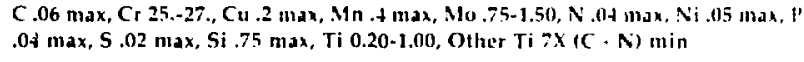 \\
\hline 5. & AISI 304L sS & UNS S30403 & $\begin{array}{l}\text { C 0.030 max, Cr 18.00-20.00, Mn } 2.00 \mathrm{max} \text {, Ni 8.00-12.00, l'0.045 max, s } 0.0301 \mathrm{max} \text {, } \\
\text { Si } 1.00 \mathrm{max}\end{array}$ \\
\hline 6. & A!SI 321 ss & UNS S32100 & 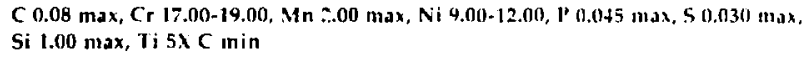 \\
\hline 7 & AISI $316 \mathrm{~L}$ ss & UNS S31603 & $\begin{array}{l}C 0.030 \mathrm{max}, \mathrm{Cr} 16.00-18.00, \text { Mn } 2.00 \mathrm{max}, \mathrm{Mo} 2.00-3.00, \mathrm{Ni} 10.00-14.00, \mathrm{~V} 0.14 .5 \\
\text { max, } 50.030 \mathrm{max}, \mathrm{Si} 1.00 \mathrm{max}\end{array}$ \\
\hline 8. & AlSI 317L ss & UNS S31703 & 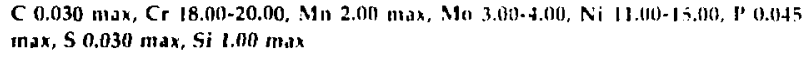 \\
\hline 9. & Nitronic 33 ss & UNS $\$ 24000$ & 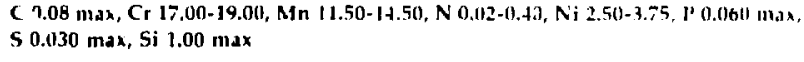 \\
\hline 10. & JS $700 \mathrm{ss}$ & UNS N08700 & 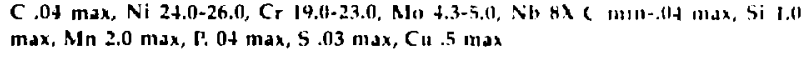 \\
\hline 11. & Ferralium 255 ss & UNS 532550 & $\begin{array}{l}\text { C .04 max, Cr 24.0-27.0. Wo 2.0-4.0, Ni 4.5-t.5, Si } 1.0 \text { max, Mn } 1.5 \text { max, N .111-.25, } \\
\text { Cu 1.5-2.5 }\end{array}$ \\
\hline 12. & Incoloy 825 & UNS N08825 & 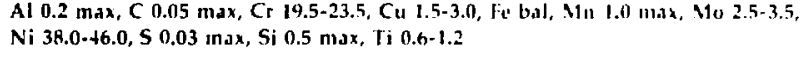 \\
\hline 13. & Inconel 625 & UNS N06625 & 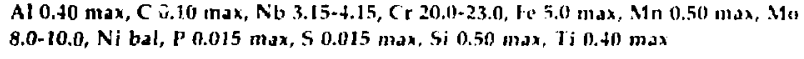 \\
\hline 14. & Ti Grade 2 & UNS R50400 & C 0.10 max, H $0.015 \mathrm{max}$, Ie $0.30 \mathrm{max}, \mathrm{N} 0.03 \mathrm{max}, \mathrm{O} 0.25 \mathrm{max}$, Ii Rem \\
\hline 15. & Ti Grade 12 & - & N .03 max, C.08 max, $11.015 \mathrm{max}$, le $.3 \mathrm{max}, 0.25 \mathrm{max}$, Mo.2-.4, Ni .h-.9. Ti Re'n \\
\hline 16. & $\operatorname{Zr} 702$ & UNS R60702 & $\begin{array}{l}\text { C } 0.05 \mathrm{max}, H 0.005 \mathrm{max}, 11 \mathrm{f} 4.5 \mathrm{max}, \mathrm{N} 0.025 \mathrm{max}, \text { Other } 7 \mathrm{r} \cdot \text { IIf } 99.2 \mathrm{~min}, \mathrm{Fe} \\
\text { Cr } 0.2 \mathrm{max}\end{array}$ \\
\hline 17. & Cupronickel $70 / 30$ & UNS C71590 & 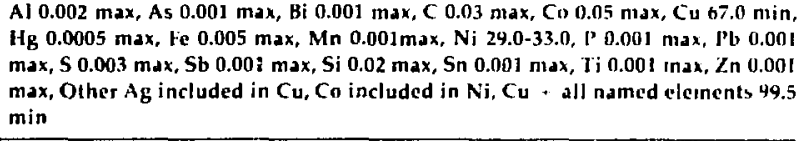 \\
\hline
\end{tabular}

References 4 through 7. 
good icldability. The two low-carbon steels that we considered are AISI 1020 and ASTM A537B. Carbon steel is the reference metal for horizontal borehole liners, based on its low cost and projected survival suring the retrieval period.

Nlloying cariom steels with chromium and molybdenum increaces the corrosion resistance under oxidizing conditions. The ferritic alloy stens under consideration are expected to resist atlack by pitting and crevice corrosion as well as stress-corrosion cracking. The shortcominge of this group are low facture toughness solues and poor we ktability. The forritic alloy steels considared are AST f(i) Ti stotbilized stamkens steel and 26 Cr 1 Mountainless sterd.

\section{Iron-Base to Nickel-Base Alloys with an Austenitic Structure}

The NNWSI reference canister and owerpack metal, which also is the reference for the DHI.W and ClHIW pour-canisters, is AISI 3041. stamless steel. The engineering properties of 3041 . stainless steel rate very well, with the exception of susceptibility to localized corrosion and to stresscorrosion cracking. If intergranular stresscorrosion cracking is excessive for 3041. stainless steel in the Topopah Spring environment, other stabilized austenitic stainless steels such as 321 stainless steel, or nickel-base allors, such as Incoloy 825, are sppropriate choices. If tranngrainular stress-corrosion cracking is a proh- lem for the austenitic stainless steels, an alloy with greater than $20 \%$ nickel content, ${ }^{, 4}$ such as Incoloy 825 , is appropriate.

If pitting and/or crevice corrosion attack is excessive in 304l. stainless steel, then an alloy with increased molvbdenum, e.g., AISI 316L and AISI 317I. stainless steels, or Incoloy 825 , will increase the resistanco to these forms of corrosion. All of the 300 series stainless steels may be specified with the extra-low carbon (0.02 max) modification to aroid sensitzation in the hightomperature glasmpouring process, and in the fircal top-caf weld on cani-tur and overpacks.

\section{Copper, Titanium, and Zirconiunir- Base Alloys}

The titanium allows are expected to be very resintant to conditions that may occur in a strong feld of pamma radiation. These alloys are also iery resistant to localized forms of corrosion, bet lose most of their mechanical strength at $800 \mathrm{C}$. When compared to the other metals, cupronickel 70/30 has competitive strength and weldability propertien, but is volnerable to corrosion by nitric acid and other oxistising species in a radiolyzed air-water environment. Zirconium alloy's have proven ferformance in aqueous, ratiolyzed envi. romments. but exhibit low mechanical strength. at fol $C$, an well as marginal fracture toughness values at - $18 \mathrm{C}$, and are the most costly of the candidate metals comsidered

\section{Metals Data}

A summary of all of the metals data obtained is presented in Tables $5,7,8$ and 9 . All references used to obtain these data are listed in Appendix $C$.

\section{Corrosion Data}

The corrosion data presented in Table 5 were assembled utilizing literature data and judgment hased upon experience. These data were used to rank the candidate matorials and subsequently seleat the top contenders. These data are presented in commonly used units of mils per year and are for unirradiated conditions. The estimated probability factors shown represent an attempt to rank the corrosion mechanisms according to their estimated selative contributions toward producing ul- timate foilure in the repository environment for each candidate metal. These estimates are helieved to be conservative, but are not meant to be applied as design data for dimensioning canister and overpack wall thicknesses for corrosion allowance.

There is abundant evidence in the literature, 10 dating back as early as 1910, that when moist air is irradiated with ionizing radiation, nitric acid will form. In ractiation corrosion experiments with moist air," it it has generally been found that metals known to be vulnerable to corrosion by nitric acid also corrode in irradiated, moist air. It is difficult to estimate accurately the increase in corrosion rates due to irradiation. For conditions in the tuff repository, the relative increases in corrosion rates would probably be significant for 
Table 5. Estimated relative maximum corresion rates for selection of candidate metals. (See Table 3 for :eference corrosion environment.)

\begin{tabular}{|c|c|c|c|c|c|c|c|c|c|c|c|c|c|c|c|c|}
\hline \multirow{3}{*}{$\begin{array}{c}\text { Material } \\
\text { designation } \\
\text { or composition }\end{array}$} & \multirow{3}{*}{$\begin{array}{l}\text { Steam } \\
\text { (mpy) }\end{array}$} & \multirow{3}{*}{$\begin{array}{l}\text { Moist air } \\
\text { condition } \\
\text { (mpy) }\end{array}$} & \multicolumn{8}{|c|}{$\begin{array}{l}\text { Continuous air/water film } \\
\text { osion mechanisms, cates (mils/yr), probabilities }\end{array}$} & \multicolumn{6}{|c|}{ Strens corrosion eracking } \\
\hline & & & \multicolumn{2}{|c|}{ General } & \multicolumn{2}{|c|}{ Pitting } & \multicolumn{2}{|c|}{ Crevice } & \multicolumn{2}{|c|}{ Intergran. } & \multicolumn{2}{|c|}{ Intergran. } & \multicolumn{2}{|c|}{ Transgran } & \multicolumn{2}{|c|}{$\mathrm{H}_{2}$ embrit. } \\
\hline & & & Rake & Prob. & Rote & Prob. & Rate & Prob. & Hate & Prob. & Rate & Proh. & Rate & Prab. & Rate & Prob. \\
\hline AIS1 1020 stcel & 0.05 & 2 & $\boldsymbol{s}$ & 0.2 & 30 & 0.5 & 40 & 0.3 & & & & & & & & \\
\hline A537 steel & 0.05 & 2 & 8 & 0.2 & 30 & 0.5 & 40 & 0.3 & & & & & & & & \\
\hline 409 st. stcel & 0.02 & 0.1 & 0.8 & 0.55 & 5 & 0.3 & 25 & 0.1 & & & & & & & 80 & 0.05 \\
\hline $26 \mathrm{Cr}-1$ Mo steel & 0.02 & nil & 0.04 & 0.6 & 10 & 0.05 & 10 & 0.15 & 40 & 0.05 & 40 & 0.05 & & & 80 & 0.15 \\
\hline 304L st. sted & 0.02 & nil & 0.04 & 0.2 & 30 & 0.15 & 40 & 0.3 & no & 0.15 & 60 & 0.15 & 100 & 0.05 & & \\
\hline 321 st. stecl & 0.02 & ni! & 0.04 & 0.2 & 30 & 0.15 & 40 & 0.3 & 31) & 0.15 & 30 & 0.15 & 100 & 0.05 & & \\
\hline 316L st. steel & 0.02 & nil & 0.04 & 0.3 & 10 & 0.1 & 15 & 0.25 & 60 & 0.15 & 60 & 0.15 & 100 & 0.05 & & \\
\hline $317 \mathrm{~L}$ st. stcel & 0.02 & nil & 0.04 & 0.4 & 5 & 0.05 & 8 & 0.20 & 60 & 0.15 & 60 & 0.15 & 169 & 0.05 & & \\
\hline Nitronic 33 & 0.02 & nil & 0.04 & 0.2 & 0 & 0.15 & 40 & 0.3 & 60 & 0.15 & 40 & 0.15 & 100 & 0.95 & & \\
\hline I5 700 & 0.02 & nil & 0.04 & 0.2 & 3 & 0.15 & 6 & 0.3 & 40 & 0.15 & 40 & 0.35 & 30 & 0.05 & & \\
\hline Ferralium $\$ 55$ & 0.02 & nil & 0.04 & 0.3 & 10 & 0.1 & 15 & 0.25 & so & 0.15 & $\therefore 0$ & 0.10 & 100 & 0.05 & 80 & 0.35 \\
\hline Incoloy 825 & 0.02 & nil & 0.04 & 0.6 & 2 & 0.1 & 4 & .15 & 30 & 0.05 & 30 & 0.05 & 100 & 0.05 & & \\
\hline Inconel 625 & 0.02 & siil & 0.04 & 0.7 & I & 0.1 & 2 & 0. & 30 & 0.05 & 30 & 0.05 & & & & \\
\hline Ti Cade 2 & 0.02 & nil & 0.04 & 0.8 & 1 & 0.05 & 2 & 0.05 & & & & & & & 200 & 0.1 \\
\hline Ti Code 12 & 0.02 & nil & 0.94 & 0.8 & c. 2 & 0.05 & 0.5 & 0.05 & & & & & & & 200 & 0.1 \\
\hline Zr 702 & 0.02 & nil & 0.04 & 0.8 & 0.2 & 0.05 & 0.5 & 0.05 & & & & & & & 200 & 0.1 \\
\hline $\mathrm{Cu}-\mathrm{Ni} 30$ & 0.02 & 0.06 & 0.2 & 0.3 & 0.6 & 0.3 & 1.0 & 0.3 & $20 \%$ & $0 . I^{c}$ & & & & & & \\
\hline
\end{tabular}

- Data not to be used for prediction of corrosion rates.

" To convert mils/yr to $\mu \mathrm{m} / \mathrm{yr}$, multiply by 25.4 .

cDealloying phenomenon. 
Table 6. Underground environments.

\begin{tabular}{|c|c|c|}
\hline & Topopali Spring ${ }^{3}$ tuff & $\begin{array}{l}\text { Chino silt loam } \\
\text { (14-yr data) }\end{array}$ \\
\hline $\begin{array}{l}\text { Chemical concentrations } \\
\text { of water extract (ppm) }\end{array}$ & $\begin{array}{l}\mathrm{SiO}_{2}-61.0, \mathrm{Na}-51.0 \\
\mathrm{~K}-4.9, \mathrm{Ba}-.003, \mathrm{Ca}-14.0 \text {, } \\
\mathrm{Mg}-2.1, \mathrm{Fe}-0.04 \text {, } \\
\mathrm{Al}-0.03, \mathrm{~F}-2.2, \mathrm{Cl}-7.5, \\
\mathrm{NO}_{3}-5.6, \mathrm{SO}_{4}-22.0 \\
\mathrm{Li}-0.05, \mathrm{Sr}-0.05 \\
\mathrm{PO}_{4}=0.12, \mathrm{HCO}_{3}-120.0\end{array}$ & $\begin{array}{l}\mathrm{Na}+\mathrm{K}-76.5, \mathrm{Ca}-124, \mathrm{Mg}-22 \\
\mathrm{HCO}+1.3, \mathrm{Cl}-60.5 \\
\mathrm{SO}_{4}-169\end{array}$ \\
\hline Water & $8 \mathrm{~mm} / \mathrm{yr}$ (net) & $\begin{array}{l}386 \mathrm{~mm} / \mathrm{yr} \text { (average rainfall furnished by the } \\
\text { US Weather Bureau) }\end{array}$ \\
\hline Resistivity & high & low \\
\hline $\mathrm{pH}$ & - neutral & - neutral \\
\hline Redox & oxidizing & oxidizing \\
\hline Air-pore space & $17 \%$ & $16 \%$ \\
\hline Moisture percentage & $14 \%$ & $26 \%$ \\
\hline Interital Draitrage & good & good \\
\hline Almosphere & air-water/filni-steam & air-Water/film \\
\hline Temperature & $29-250^{\circ} \mathrm{C}$ & $10^{\circ} \mathrm{C}-28^{\circ} \mathrm{C}^{18}$ \\
\hline Radiation ficld & $\begin{array}{l}\text { gamma (CHLW), } \\
1.1 \times 10^{5} \mathrm{rem} / \mathrm{hr} \max \end{array}$ & background \\
\hline Areal thermal loading & $50 \mathrm{~kW} / \mathrm{acre}$ (iniljal) & solar \\
\hline Corrosion products & scale & scale \\
\hline \multicolumn{3}{|l|}{ Pitting Corrosion Data } \\
\hline AJSI 304 s. stl. & TBD (to be determined) & $1.1 \mathrm{mpy}(28 \mu \mathrm{m} / \mathrm{yr})$ \\
\hline AISI 316 s. stl. & TBD & $4 \times 10^{5} \mathrm{mpy}\left(10^{3} \mu \mathrm{m} / \mathrm{yr}\right)$ \\
\hline AISI 430 s. stl. & TBD & $4.4 \mathrm{mpy}(112 \mu \mathrm{m} / \mathrm{yr})$ \\
\hline AISI 410 s. stl. & TBD & $4.4 \mathrm{mpy}(112 \mu \mathrm{m} / \mathrm{yr})$ \\
\hline
\end{tabular}

Table 7. Estimated costs of candidate metals.

\begin{tabular}{|c|c|c|c|}
\hline Material & $\begin{array}{c}\text { Raw material } \\
\text { cost (plate) } \\
\left(\$ / \text { in. }^{3}\right)^{3}\end{array}$ & $\begin{array}{l}\text { Manufacturing cost } \\
\text { for } 1 / 2 \text {-in. wall. } \\
\text { welded pipe }\left(\$ / \text { in. }{ }^{3}\right)^{0}\end{array}$ & $\begin{array}{l}\text { Total cost } \\
\left(5 / \text { in. }^{3}\right)\end{array}$ \\
\hline AISI 1020 steel & 0.1 & 0.2 & 0.3 \\
\hline A537 steel & 0.1 & 0.2 & 0.3 \\
\hline $409 \mathrm{Ti}$ stabil. st. steel & 0.3 & 0.3 & 0.6 \\
\hline $26 \mathrm{Cr}-1 \mathrm{Mo}$ steel & 1.1 & 0.3 & 1.4 \\
\hline 304L st. steel & 0.4 & 0.2 & 0.6 \\
\hline 321 st. steel & 0.5 & 0.2 & 0.7 \\
\hline 316L st. steel & 0.5 & 0.2 & 0.7 \\
\hline $317 L$ st. steel & 0.6 & 0.2 & 0.8 \\
\hline Nitronic 33 st. steel & 0.4 & 0.2 & 0.6 \\
\hline IS 700 st. steel & 1.0 & 0.3 & 1.3 \\
\hline Ferraiium 255 st. steel & 0.7 & 0.5 & 1.2 \\
\hline Incoloy 825 & 1.2 & 0.5 & 1.7 \\
\hline Inconel 625 & 2.6 & 0.5 & 3.1 \\
\hline Ti Code 2 & 1.6 & 0.5 & 2.1 \\
\hline Ti Code 12 & 1.8 & 0.5 & 2.3 \\
\hline $\operatorname{Zr} 702$ & 3.5 & 0.6 & 4.1 \\
\hline CDA 715 (copper-nickel 70/30) & 1.0 & 0.4 & 1.4 \\
\hline
\end{tabular}

"To convert $\$ / \mathrm{in}^{3}$ to $\mathrm{S} / \mathrm{cm}^{3}$, multiply by $6.1 \times 10^{-2}$. 
Table 8. Mechanical properties of candidate metals.

\begin{tabular}{|c|c|c|c|c|c|c|}
\hline \multirow[b]{2}{*}{ Material } & \multirow{2}{*}{$\begin{array}{l}\text { Tensile strength } \\
\text { (ksi) }\end{array}$} & \multirow{2}{*}{$\begin{array}{l}\text { Yield strength } \\
\text { at } 800^{\circ} \mathrm{C} \\
\text { (ksi) }\end{array}$} & \multirow{2}{*}{$\begin{array}{l}\text { Elongation (\%) } \\
\text { minimum } \\
\text { static }\end{array}$} & \multirow{2}{*}{$\begin{array}{c}\text { Nil ductility } \\
\text { (emperature }\left({ }^{\circ} \mathrm{C}\right) \\
\text { for } 1 / 2 \text {-in.-thick plate }\end{array}$} & \multicolumn{2}{|c|}{$\begin{array}{l}\text { Fracture toughness } \\
\text { minimum at }-18^{\circ} \mathrm{C}\end{array}$} \\
\hline & & & & & $\left(f(-1 b)^{b}\right.$ & $\left(k s i-i n .^{1 / 2}\right)^{c}$ \\
\hline AISI 1020 steel & 60 & 8 & 30 & -18 & 8 & - \\
\hline A537 stcel & 80 & 8 & 22 & -30 & 40 & 107 \\
\hline 409 Ti stabil. st. steel & 70 & 5 & 25 & -29 & 20 & - \\
\hline $26 \mathrm{Cr}-1 \mathrm{Mo}$ steel & 70 & 7 & 20 & -18 & 20 & - \\
\hline 304L st. steel & 80 & 12 & 40 & $<-148$ & 100 & 142 \\
\hline 321 st. steel & 85 & 13 & 40 & $<-148$ & 90 & 129 \\
\hline 316L st. steel & 80 & 13 & 40 & $<-148$ & 110 & 150 \\
\hline $317 \mathrm{~L}$ st. steel & so & 18 & 40 & $<-148$ & 100 & 156 \\
\hline Nitronic 33 & 115 & 20 & 40 & $<-148$ & 43 & 123 \\
\hline IS 700 & 85 & 19 & 40 & $<-148$ & 100 & 147 \\
\hline Ferralium 255 & 124 & 25 & 25 & -18 & 100 & - \\
\hline Incoloy 825 & 95 & 23 & 30 & $<-148$ & 78 & 150 \\
\hline Inconel 625 & 135 & 45 & 40 & $<-148$ & 44 & 130 \\
\hline Ti Code 2 & 50 & 1 & 21 & $<-148$ & 30 & 65 \\
\hline Tí Code 12 & 70 & 3 & 18 & -18 & 11 & 35 \\
\hline $\mathrm{Zr} 702$ & 55 & 1 & 16 & -18 & 11 & 35 \\
\hline CDA 715 (copper-nickel 70/30) & 44 & 17 & 37 & $\therefore \quad 148$ & 113 & - \\
\hline
\end{tabular}

- To convert ksi to MPa, multiply by 6.9.

h To convert ft-tb to joules, multiply by 1.36 .

'To convert ksi-in. ${ }^{1 / 2}$ to MPA-m ${ }^{1 / 2}$, multiply by 0.18 . 
Table 9. Weldability parameters for candidate metals."

\begin{tabular}{|c|c|c|c|c|c|c|c|c|c|}
\hline $\begin{array}{c}\text { Material } \\
\text { designation } \\
\text { or composition }\end{array}$ & Preheat & $\begin{array}{l}\text { Special } \\
\text { interpass } \\
\text { temp. }\end{array}$ & $\begin{array}{l}\text { Post- } \\
\text { heat } \\
\text { treat }\end{array}$ & $\begin{array}{c}\text { Special } \\
\text { atm. }\end{array}$ & $\begin{array}{c}\text { Low } \\
\text { weld, } \\
\text { HAZ } \\
\text { toughness }\end{array}$ & $\begin{array}{c}\text { Non- } \\
\text { standard } \\
\text { process }\end{array}$ & $\begin{array}{l}\text { Non- } \\
\text { standard } \\
\text { NDE }\end{array}$ & $\begin{array}{l}\text { Non- } \\
\text { econ. } \\
\text { rel. } \\
\text { to A BSI } \\
304\end{array}$ & $\begin{array}{c}\text { Special } \\
\text { fit-up }\end{array}$ \\
\hline AISI 1020 sted & 0 & 0 & 0 & o & 0 & 0 & 0 & 0 & 0 \\
\hline A537 strel & 0 & $\mathbf{I}$ & 0 & a & 0 & 0 & $\mathbf{0}$ & 0 & 0 \\
\hline 404 Ti statiil. st. steel & 1 & 1 & 1 & 0 & 1 & o & 0 & 1 & 0 \\
\hline 26 $\mathrm{Cr}-1 \mathrm{Mo}$ st. steel & 0 & 0 & 1 & 1 & 1 & 0 & $\mathbf{0}$ & 1 & 1 \\
\hline 30.11. st. steel & 0 & 0 & 0 & 0 & 0 & 0 & n & 0 & 0 \\
\hline 321 st. steel & n & (1 & 0 & a & 0 & 0 & $\mathbf{0}$ & 0 & 0 \\
\hline $316 t$ st. stuel & 0 & 0 & 0 & 0 & 0 & 0 & 0 & 0 & $\mathbf{0}$ \\
\hline 3171 st. stuel & 0 & n & n & 0 & 0 & 0 & 0 & 1 & 0 \\
\hline Nitronic 3.3 st. sted & 0 & 0 & 0 & 0 & 0 & 0 & 0 & 1 & 0 \\
\hline 1S 700 st. sted & 1 & 1 & 1 & 0 & 0 & 0 & 0 & 1 & 1 \\
\hline ferralium 255 st. sterel & 0 & 1 & 0 & 0 & 0 & 0 & 0 & 0 & 1 \\
\hline Incoloy 825 & 0 & 0 & 0 & 0 & 0 & 0 & 0 & 1 & 1 \\
\hline Inconel 625 & 0 & 0 & o & ( & 0 & 0 & 0 & 1 & 1 \\
\hline Ti Code 2 & 0 & 0 & 0 & 1 & 0 & i) & 0 & 1 & 1 \\
\hline Ti Code 12 & 0 & 0 & 0 & 1 & 1 & 0 & 1 & 1 & 1 \\
\hline $\operatorname{Zr} 702$ & 0 & 0 & 0 & 1 & 1 & 0 & 0 & 1 & 1 \\
\hline CDA 715 (copper-nickel $70 / 30)$ & 0 & 1 & 0 & 0 & 0 & 0 & 0 & 1 & 1 \\
\hline
\end{tabular}

Yes (1) or no (0) special problems.

"Heat-affected zone.

copper-based alloys. Makepeace ${ }^{i t}$ reported a 6-month irradiation experiment which indicated that certain austenitic stainless steels and nickelbase alloys had very low corrosion rates in moist air irradiated with a gamma-ray. flux of 5 to 6 megarads per hour at ambient teripperature. Under the same conditions, copper samples showed higher corrosion rates. Although this experiment was carried out at a higher dose rate, a lower temperature, and for much shorter times than are of interest for the tuff repository, the results are indicative of the type of corrosion behavior to be expected under irradiation conditions.

Presently no long-term underground corrosion data exist for our candidate metäls in an environment exactly like that at Yucca Mountain ${ }^{17}$ (see Appendix A for a detailed description of the Yucca Mountain corrosion environment). However, underground corrosion data for a few of the candidate metals were found for Chino silt lnam for a 14-year test. ${ }^{15}$ Table 6 lists the significant attributes of hoth environments and presents available data. Figure 4 compares the two environments schematically. The data presented in Table 6 indicate the following for the Chino silt loam environment:
- A Mo-containing austenitic stainless steel (e.g., type 316) performed better than an ordinary $\mathrm{Ni}-\mathrm{Cr}$ austenitic stainless steel (e.g., type 304).

- Ferritic staunless steels (e.g., types 430 and 410) did not perform as well as 304 stainless steel.

Performance was determined by general corrosion and pitting corrosion rates on coupons of these alloys buried in soil. Relationships between the corrosivity of soils and factors such as soil resistivity, $\mathrm{pH}$, aeration, and the corrosion products formed have been suggested in the literature. ${ }^{15.16}$

Although major differences are shown between the Chino silt loam environment and the Topopah Spring tuff of Yucca Mountain environment, there are also some similarities, and these data represent "best guesses" for long-term underground conditions until site-specific data for the repository environment become available.

\section{Material aud Fabrication Costs}

Rolled and welded pipe manufacturing processes are representative of the kind of fabrication involved in manufacturing overpacks. Diameters 
Topopah Spring Tuff

Environment,

1000-year exposure,

Corrosion rate under investigation.

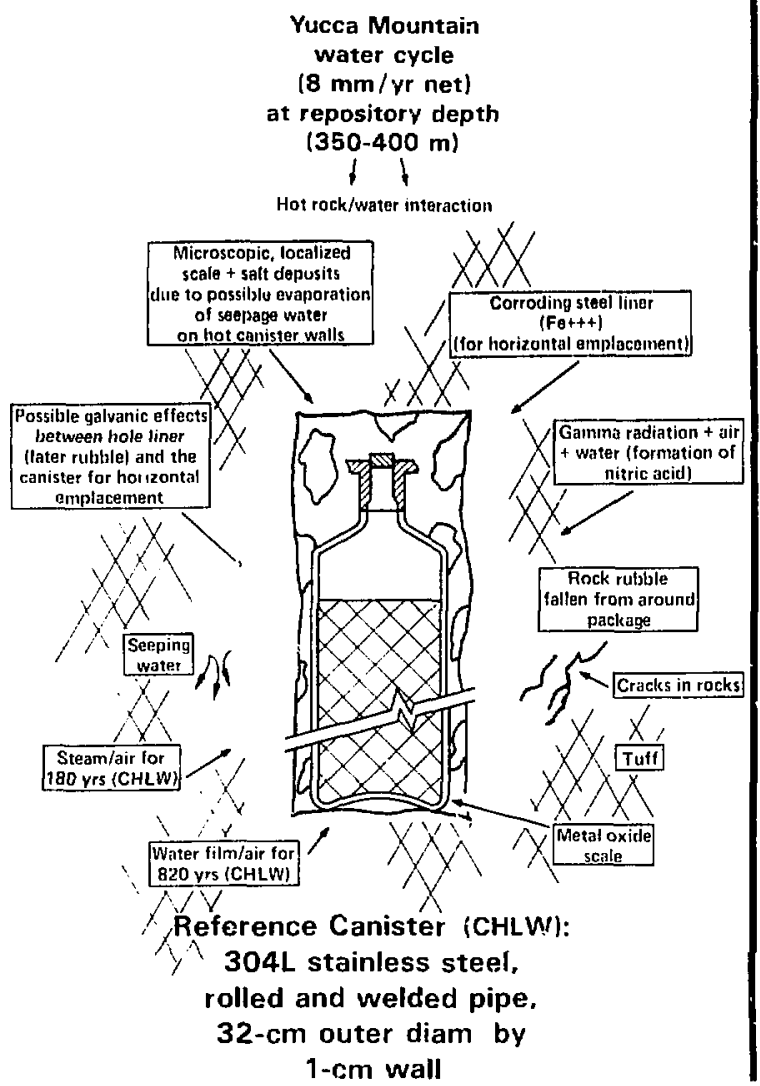

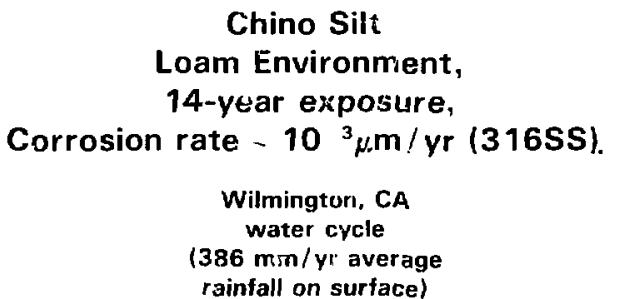

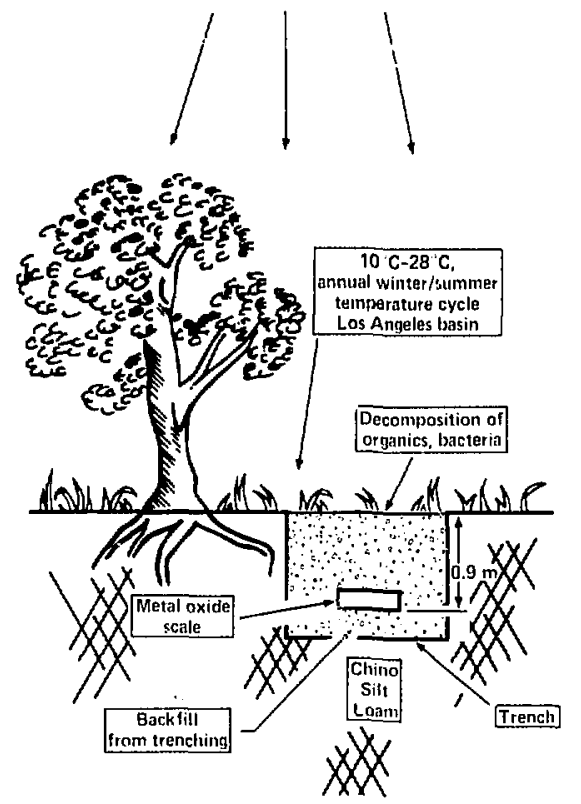

Specimens:

$304 / 316$ stainless steel plate. 1.6- $\mathrm{mm}$ thick

Figure 4. Comparison of underground c - ision environments.

of 0.3 to $0.91 \mathrm{~m}$ represent the upper limit of canister and overpack diameters that we contemplate in our designs, so we used the cost of $0.91-\mathrm{m}$ (36in.) diam by $12.7-\mathrm{mm}(1 / 2-i n$.) wall, welded pipe as a measure. These costs were ohtained by telephone contact with commercial fabricators. The costs of alternative fabrication processes such as extrusion and centrifugal casting were also considered, but were rejected due to high cost or failure to meet our minimum design requirements. Table 7 shows the costs of the candidate metals.

\section{Desired Mechanical Properties}

Certain mechanical properties are important in this application: Iracture toughness at $255 \mathrm{~K}$ $\left(-18^{\circ} \mathrm{C}\right)$, elongation, nil-ductility temperature, tensile strength, and yield strength at $1073 \mathrm{~K}$ $\left(800^{\circ} \mathrm{C}\right)$. Fracture toughness at lowest ambient temperature is a property of a material that de fines its resistance to brittle fracture. This property is dictated by the requirement that the waste package survive a drop test from a height of two 
times the package length without leaking. During transportation and at Yucca Mountain, minimum handling temperatures are roughly $255 \mathrm{~K}$ $\left(-18^{\circ} \mathrm{C}\right)$. The ductility (elongation) is also important to the drop test requirement. The fracture toughness of certain alloys exhibits significant variations with changes in temperature. The nilductility temperature is that temperature below which normally ductile materials behave in a britthe rashion.

The ultimate tensile strength is a measure of the stress which will lead to fracture of the material. The margin between the yield strength and the ultimate strength is a measure of the degree to which stretching and bending rather than fracture takes place after the yield strength is exceeded. Actual designs will load the material to a stress below the yield strength, including a factor of safety. The yield strength at $1073 \mathrm{~K}\left(800^{\circ} \mathrm{C}\right)$ is related to high temperature glass pouring operations and to the requirement of surviving a $1073 \mathrm{~K}$ $\left(800^{\circ} \mathrm{C}\right), 30$-minute fire test without leaking. Table 8 summarizes the mechanical properties data.

\section{Weldability}

The waste package containment barrier will have several welded joints. The final weld of the top-cap to the main overpack and canister bodies will be done remotely. Table 9 lists the weldability data. Possible welding problems were identified by yes (1) or no ( 0 ) binary evaluation of the following characteristics: preheat requirements, special interpass temperature, postheat requirements, special welding atmosphere, low weld toughness, nonstandard weldirig process, nonstandard nondestructive evaluation process, special cleanliness during fit-up, and not economical relative to 304 stainless steel. The overall weldability also includes all dimensional and mechanical property requirements of the weld and heat-affected zone.

Extensive discussions on weldability were held with H. Weiss, P. Landon, C. Witherell, all LLNL; J. Lippold, Sandia National Laboratories; and metals suppliers and pipe fabricators.

\section{Ranking of Candidate Metals}

The 17 candidates have been ranked according to the data shown in Tabies 5, 7,8, and 9. Each factor (corrosion resistance, cost, mecharical properties, and weldability) was given the same weighting. A score of 0 was designated for "some disadvantages", 1 for "suitable" and 2 for "superior." Table 10 shows the results.

Table 10. Ranling summary for candidate metals.

\begin{tabular}{|c|c|c|c|c|c|c|}
\hline $\begin{array}{l}\text { Material } \\
\text { designation }\end{array}$ & $\begin{array}{l}\text { Corrosion } \\
\text { resistance" }\end{array}$ & $\begin{array}{l}\text { Mechanical } \\
\text { properties }\end{array}$ & Weldability & $\operatorname{Cos} t^{n}$ & Score & Rank $^{\text {' }}$ \\
\hline AISI 1020 steel & n & 1 & 2 & 2 & 5 & 3 \\
\hline A537 sled & n & 2 & 1 & 2 & 5 & 3 \\
\hline 409 st. stcel & $\mathbf{1}$ & 1 & 1 & 1 & 4 & 3 \\
\hline $26 \mathrm{Cr}-1 \mathrm{Mo}$ sted & 1 & 1 & 0 & 0 & 2 & 3 \\
\hline $304 \mathrm{~L}$ st. steel & 1 & 2 & 2 & 2 & 7 & 1 \\
\hline 321 st. sted & 1 & 2 & 2 & 2 & 7 & 1 \\
\hline $316 \mathrm{~L}$ st. steel & 1 & 2 & 2 & 2 & 7 & 1 \\
\hline 317L st. steel & 1 & 2 & 2 & 1 & 6 & 2 \\
\hline Nitronic 33 & 1 & 2 & 2 & 1 & 6 & 2 \\
\hline jS 700 & 2 & 2 & 0 & 1 & 5 & 3 \\
\hline Ferralium 255 & 1 & 2 & 1 & 1 & 5 & 3 \\
\hline Incoloy 825 & 2 & 2 & 2 & 1 & 7 & 1 \\
\hline Inconel 625 & 2 & 2 & 2 & 0 & 6 & 2 \\
\hline Ti Code 2 & 2 & 0 & 1 & D & 3 & 3 \\
\hline Ti Code 12 & 2 & $\mathbf{0}$ & 0 & 0 & 2 & 3 \\
\hline Zr 702 & 2 & 0 & 0 & $\mathbf{0}$ & 2 & 3 \\
\hline $\mathrm{Cu}-\mathrm{Ni} 70 / 30$ & 0 & 2 & 1 & 1 & 4 & 3 \\
\hline
\end{tabular}

${ }^{\mathrm{D}} \mathrm{O}=$ some disadvantages, $\mathrm{I}=$ suitable, $\mathrm{Z}$ = superior.

${ }^{b} 1=$ highest, $3=$ lowest. 


\section{Results and Recommendations}

Analysis of the data presented in this report resulted in selection of the four highest ranking metals out of the 17 candidates for canisters or overpacks. AISI 1020 carbon steel was chosen for hole liners. Summary statements are given on these metals.

AISI 304L Stainless Steel: a low carbon, general-purpose austenitic stainless steel. We will further specify a premium grade with an extra'low carbon content of less than $0.02 \% \mathrm{C}$ if experimental results and analysis indicate that chromium carbide precipitation (sensitization) will occur during welding and glass pouring.

AISI 321 Stainless Stecl: a general-purpose, austenitic stainless steel with a titanium addition for stabilization of the carbon, thus preventing the formation of chromium-carbides (sensitization) during welding and glass pouring, as well as over long periods of time, at low temperatures (100$300^{\circ} \mathrm{C}$ ).

AISI 316L Stainless Stecl: a low carbon, austenitic stainless steel with the addition of $2-3 \%$ molybdenum for more resistance to pitting corrosion than type $304 \mathrm{~L}$. We will further specify a premium grade with an extra low carbon content of less than $0.02 \% \mathrm{C}$ if experimental results and analysis indicate that chromium carbide precipitation (sensitization) will occur during welding and glass pouring

Incoloy 825: a nickel-iron-chromiumnolybdenum-copper austenitic alloy designed for use in extremely corrosive environments. This alloy is stabilized with titanium to resist intergranular corrosion and intergranular stress corrosion rracking. The nickel content makes it very resistant to transgranular stress corrosion cracking. The molybdenum and copper give this alloy resistance to pitting and crevice corrosion. The high chromium content gives it resistance to various types of oxidizing environments.
AISI 1020 Steel: a low carbon, generalpurpose steel, for horizontal borehole liners, appropriate for a 50-year retrieval period. AISI 1020 steel has satisfactory properties for use as hole liners and is very attractive from a cost standpoint.

The remaining materials were not selected for the following reasons:

- ASTM A537B steel: low corrosion resistance for overpacks and canisters, and more expensive compared to AISI 1020 steel for horizontal borehole liners.

- AISI 409 atainless steel: relative weldability problems.

- $26 \mathrm{Cr}-1$ Mo steel: relative weldability problems.

- AISI 317L stainless steel: more expensive compared to AISI 316L stainless steel, with linited improvenent in corrosion resistance.

- Nitronic 33: more expensive compared to AISI 304L stainless steel, with minor improvement in properties.

- IS 700: more expensive compared to AISI 304L. stainless steel and weldability problems.

- Ferralium 255: unacceptable nil-ductility temperature and more expensive than AISl 304L stainless steel. 825.

- Inconel 625: more expensive than Incoloy $800^{\circ} \mathrm{C}$

- Ti Code 2: expensive, low yield strength at

- Ti Code 12: expensive, relative weidability problems, low fracture toughness.

- $\operatorname{Zr}$ 702: expensive, relative weldability problems, baw tracture toughness.

- Cupronickel 70/30: low corrosion resistance in gamma-irradiated moist air and aerated water.

\section{Conclusion}

The results of our analysis show the five metals that best satisfy the requirements for disposal of high-level waste at the NNWSI-proposed repository at Yucca Mountain. Testing is presently planned or in progress on these metals for further development of the waste package design for the unsaturated zone. The reference canister and overpack metal is AISI $304 \mathrm{~L}$ stainless stee], but alternative metals will also be considered for reasons previously discussed. The primary alternative metals have been selected from the list of the 17 candidate metals discussed in this report. They are AISI 321, AlS1 316L, lncoloy 825 for canisters and overpacks, and 1020 carbon steel for borehole liners. 


\section{Acknowledgment}

The authors wish to express appreciation to $\mathrm{D}_{1}$. Richard $\mathrm{Vin}$ Fonynenturg for his thorough review of this report.

\section{References}

1. Federal Register, Vol. 48, No. 120, 10 CFR 60, "Disposal of High-Level Radioactive Wastes in Geologic Repositories Technical Criteria," Nuclear Regulatory Commission, Final Rule, June 21, 1983.

2. W. C. O'Neal, A. J. Rothman, D. W. Gregg, J. N. Hockman, M. A. Revelli, E. W. Russell, and J. R. Schornhorst, Design of a Nuclear Wiste Packuge for Emmiacement in Fuff, Lawrence Livermore Nationa] Laboratory, Livermore, CA, UCRL..88192 (1983).

3. J. R. Schornhorst et al., Concephnal Waste Package Designs for Disposal of Nuclear Wiste in Tuff, Westinghouse AESD, Pittsburgh, PA, ONWI-439, April 1983 Battelle, Office of Nuclear Waste Isolation, Columbus, $\mathrm{OH}$.

4. Society of Automotive Engineers and American Society for Testing and Materials, Unified Numbring Systeil for Motuls and Alloys, 2nd ed, (1977).

5. Armco Southwestern Steel Division, Armco Pressutre Vesscl Stecls, Technical Bulletin.

6. Timet, Ti Codr-12, Technical Bulletin.

7. Jessup Steel Co., IS 700, Technical Bulletin.

8. F. L. 1.aQue and H. R. Copson, Corrosion Resistance of Metals and Alloys (Reinhold Publishing Corp., New York, 1963).

9. Casi Histories in Failuro Analysis, P. M. Unterweiser, Ed. (American Society for Metals, Metals Park, $\mathrm{OH}, 1979)$.

10. S. C. Lind, C. J. Hochanadel, and J. A. Ghormley, Radiation Chemistry of Gases (Reinhold, New York, 1961), Chapter 13.

11. W. Primak and L. H. Fuchs, "Transportation of Matter and Radioactivity by lonized Air Corrosion," Physics Todmy 7, 15 (1954).

12. W. Primak and L. H. Fuchs, "Nitrogen Fixation in a Nuclear Reactor," Nucleonics 13, No. 3, 38 (1955).

13. A. V. Byalobzheskii, Radialion Corrosion, Izdatel" stvo "Nauka," Moskva 1967, translated by Israel Program for Scientific Translations, Jerusalem (1970).

14. C. E. Makrpeace, "Design and Analysis of Corrosion Experiments for Testing Materials Exposed to Gamma Radiation," I. of Testing and Evalunfion 2, 202 (1974).

15. M. Romanoff, Undergromend Corrosion, National Bureau of Standards Circular 579, Washington, DC (April 1957).

16. K. Nuttall and V. F. Urbanic, An Assessment of Materials for Nuclear Fucl Immobilization Containcrs, Whiteshell Nuclear Rescarch Establishment, Pinawa, Manitoba, AECL-6440 (1981),

17. M. D. Merz, State-of-the-Art Report on Corrasion Data Pertaining to Metallic Barriers for Nuclear Waste Repositories, Pacific Northwest Laboratory, Richland, WA, PNL-4474 (1982). 


\section{Appendix A. Emplacement Environment}

The NNWSI project has selected the Topopah Spring Member of the Paintbrush Tuff as the repository target horizon for a repository sited at Yucca Mountain. The repository will be located in a welded portion of the tuff unit and will lie approximately 350 to 400 meters below surface level. The static water level is over 100 meters below the repository level. The depths given here are based on information obtained from geologic and hydrologic borehules around the edge of the repository block and from the principal borehole (USW G-4) at the exploratory shaft. The exact depth of the repository horizon will be established during the exploratory shaft phase of the program.

The choice of the unsaturated zone marks a departure from the conventional environment in which repository siting has been proposed. There are many characteristics of the unsaturated zone which make use of this regime particularly attractive for a high-level waste repository site. Several advantages of the unsaturated zone over the saturated zone are described below:

- The waste canisters will not be submerged in a continuum of water. Rather, they will be subjected to constant contact with water vapor and to intermittent contact with limited amounts of liquid water.

- The pressure exerted on the canisters by the environment will be approximately 1 atmosphere. There is no hydrostatic pressure because there is not a continuum of water above or around the canisters.

- The environment to which the canister is exposed will be of air plus water vapor, it the temperature is more than $100^{\circ} \mathrm{C}$." This is a consequence of the absence of hydrostatic pressure.

- Aqueous corrosion of the canister or overpack can only begin after the teinperature has dropped to less than $100^{\circ} \mathrm{C}$. This is because liquid water camnot exist in the unsaturated zone at temperatures higher than $100^{\circ} \mathrm{C}$, the 1 -atmosphere boiling point of water. Calculations of thermal history for reference canisters show that for $\mathrm{CHLW}$, canister temperatures will drop below $100^{\circ} \mathrm{C}$ approximately 180 years after waste emplacement. For spent fuel packages, the canister temperature will remain $100^{\circ} \mathrm{C}$ or greater for approximately 1000 years after emplacement (see Table 3 ).

- The vadose water and atmosphere of the repository will be mildly oxidizing. This may promote the growth of a protective coating of oxidation products on the skin of metal components of the waste package. Such oxidized coatings can form protective layers against further corrosion, as in the cases of stainless steel, zirconium, and titanium.

- Water available for corrosion and waste form dissolution is limited to the small amount supplied by downward infiltration from the overlying unsaturated media, a flux currently estimated to be about 8 $\mathrm{mnn} /$ year.

- It may be pussible to resign the repository so that the limited amount of water which enters the repository area drains through the area by fracture flow. This would result in reduced contact tine for water, waste canister, and waste form, a factor which would reduce radionuclide release to very low levels.

- The low pressure in the repository means that canisters and overpacks do not need to be designed to withstand high hydrostatic pressures. The only strength requirenents for canisters and overpacks will be that they must withstand any stress conditions which might arise during normal and accident handling and emplacement operations, or during retrieval operations and expected seismic events.

\footnotetext{
"The actual boiling point of water at the repository horizon will be aluut $95^{\circ} \mathrm{C}$; for simplicity in reading, $100^{\circ} \mathrm{C}$ is used throughout this discussion.
} 


\section{Appendix B \\ Metal Components for Use as Canister and/or Overpack Materials}

The reference metal for use in overpack and canister fabrication for the NNWSI repository is 304L. stainless steel. In this section, we will provide an upper-limit estimate for the rate of uniform corrosion of this material in the unsaturated zone. We will then describe a research and development program to determine the actual rate of uniform corrosion under expected repository conditions and whether any nonuniform corrosion mechanisms can be expected to be important.

The maximum calculated ('nsumption of 304L stainless steel by uniform corrosion in Topopah Spring tuff has been calculated to be $0.12 \mathrm{~cm}$ in the first 1,000 years after waste emplacement (see following discussions). This estimate was calculated using the thermal history for CHLW and DHLW canisters, which require a larger corrosion allowance than spent-fuc! canisters. The spent-fuel corrosion allowance can be less because the canister will remain free from contact with liquid water for 770 years after emplacement (sec Table 3) (for the period from 770-1000 years, water contacting the 100 $C$ canister will flash evapromate).

Corrosion rates were estimated for 3014. stainless under three corrosion regimes. In all cases, the most conservative estimates allowed by the existing data were used. The basis for the estimates is discussed. The data used were taker, from results on types 302,304, and 304L, which differ primarily in their maximum carbon contents $(0.15,0.08$, and 0.03 percent, respectively). The carbon content at this low level should not significantly affect the rate of uniform corrosion. The enviroments defined and the corrosion rates used are as follows:

- Stean, 300 to $100^{\circ} \mathrm{C}, 0.3 \mu \mathrm{m} / \mathrm{yr}$.

- Moist air, $100^{\circ} \mathrm{C}, 1.0 \mu \mathrm{m} / \mathrm{yr}$.

- Hot aerated water, 80 to $100^{\circ} \mathrm{C}, 2.5 \mu \mathrm{m} / \mathrm{yr}$.

To allow some credit fo" the actual unsaturated conditions, the steel is presumed to be in contact with water for only half the time period when the temperature is below $100^{\circ} \mathrm{C}$.

The corrosion-oxidation rate in steam above $100^{\circ} \mathrm{C}$ was based on extrapolation of data from higher temperatures down to the repository temperature range. A $2-y e a r$ test at approximately $600^{\circ} \mathrm{C}$ in steam indicated a corrosion rate of loss than $5 \mu \mathrm{m} / \mathrm{yr}$ for 304L stainless steel. ' The corrosion attack was uniform. Data obtained for type 302 at $875^{\circ} \mathrm{C}$ in "wct" and "dry" air showed rates of 11 and $7.5 \mu \mathrm{m} / \mathrm{yr}$, respectively, after 300 hours. The rate then slowed to 9 and $4.5 \mu \mathrm{m} / \mathrm{yr}$, respectively, after 500 hours.' The thickness of metal oxidized versus time follows a parabolic rate law so that estimates of consumption hased on a linear extrapolation as done here are conservative. Stainless steels show a threshold temperature above which the oxidation rate becomes "appreciable." For the stainless steels considered here, the threshold temperature is about $900^{\circ} \mathrm{C}$. In extrapolating the availaile data to the temperature range of interest for the repository by an Arrhenius rate law, the oxidation rate in wet air becones essentially zero. However, to assign a nonzero number to the rate, the value of $0.3 \mu \mathrm{m} / \mathrm{yr}$ was selected based on the sensitivity of the experimental observations and considering the time period over which the observations were made. This value is very conservative and would not be dependent upon the actual temperature at the canister or overpack surface.

Corrosion during the period when water reenters the waste package environment (below $100^{\circ} \mathrm{C}$ ) was estimated by using the corrosion rate at the boiling point of water. The value of $1 \mu \mathrm{m} / \mathrm{yr}$ was assigned based on atmospheric corrosion of stainless steel type 304. Five-year exposure data at an industrial site in the United Kingdom yielded a rate of $0.12 \mu \mathrm{m} / \mathrm{yr}$ averaged cver the 5 -year period. During this time the atmosphere was partially controlled by the use of air pollution controls. ${ }^{2}$ This, again, is a conservative estimate since the industrial environment contains $\mathrm{SO}_{2}$ that would hydrolyze to give acidic conditions on the metal surface. Because these data were obtained at an assumed prevailing temperature of about $15^{\circ} \mathrm{C}$, they were extrapolated to $100^{\circ} \mathrm{C}$ by assuming that the corrosion rate roughly doubles for each $30^{\circ} \mathrm{C}$ increase in temperature. ${ }^{3}$ This assumes that ther is no change in the corrosion mechanism.

The corrosion rate for the bulk of a 1,000-year postemplacement period was estimated using the rate for stainless steel immersed in water which is saturated with air in the temperature range of 80 to $100^{\circ} \mathrm{C}$. To ailow some credit for unsaturated conditions, the canister or overpack was assumed to be immersed oniy half the time. Again, the assumptions involved here are very conservative. The actual conditions will involve far less water. The corrosion rate which prevails under the immersed conditions is $2.5 \mu \mathrm{m} / \mathrm{yr}$. This 
value was based on a compilation of sources. ${ }^{1.4}$ Three-year data from exposure to Mississippi River water indicated a corrosion rate for 304 of less than $2.5 \mu \mathrm{m} / \mathrm{yr}$. The same general corrosion rate was obtained for polluted acid mine runoff in Monongahela River water and for more saline Savannah River water $\{1,300$ ppm chloride). In the last case, the metal showed signs of the onset of crevice attack. Experience in boilers and with the high-purity water used in nuclear reactors shows that 304 stainless steel has negligible corrosion rates under those conditions. For example, at $260^{\circ} \mathrm{C}$ in high-purity water the rate is $1 \mu \mathrm{m} / \mathrm{yr}$, including the effects of other corrosion attack due to reactor operation. Expected general corrosion rates of $304 \mathrm{~L}$ stainless steel exposed to water typical of a repository in the unsaturated tuff are low, if the conditions described in Appendix A are correct. A general corrosion rate was assigned for this period and temperature range equal to the highest value in the range recorded from the foregoing references. This estimate will be modified as soon as results are available from the experimental program to be outlined.

The materials testing program for metal components of the waste package will focus on the 300-series austenitic stainless steels. Analysis of the data available on corrosion in a variety of environments shows that several different types of nonuniform corrosion mechanisms are of possible concern if the glass-pour canister is used as the primary containment barrier. The potential problem areas are sensitizing of the steel from the temperatures encountered during glass casting operations, pitting and crevice attack, transgranular stress corrosion, and long-term phase stability of the metal. The following paragraphs discuss the conditions under which it is expected that these factors will be of concern, and the remedies available if $304 \mathrm{~L}$ shows a nonuniform corrosion mechanism that would rule out its use as the containment barrier. Finally, an outline of the testing program is given. The program is designed to determine the corrosion rate and mechanism for the reference canister material and alternative materials under expected repository conditions.

During the manufacture of waste glass, hot liquid is poured into the canister. The canister wall is exposed to molten glass which has a temperature on the order of $1,100^{\circ} \mathrm{C}$ at the start of the pouring operation. The canister becomes heated by the glass and cools slowly as the glass cools to room temperature. The relatively low thermal conductivity of the glass (average of $1 \mathrm{~W} / \mathrm{mK}$ ) means that the canister cools slowly through a wide temperature range. The slow cooling allows aiffusion of $\mathrm{Cr}$ out of the alloy and precipitation of chromium carbides at grain boundaries. The lower the carbon content of the steel, the longer the material must be held at the high temperature for this process to occur. Figure B-1 illustrates this point. The areas to the right of the curves and enclosed by the curves are the time-temperature regions where sensitizing of the steel will occur due to chromium carbide precipitation. Following precipitation, the region surrounding the grain boundaries is $\mathrm{Cr}$-depleted and is likely to corrode at a more rapid rate than the normal alloy. The exact time-temperature history for $304 \mathrm{~L}$ pour canisters is not presently known; however, when combined with reasonable g!ass production and cooling scenarios, the curves shown in Fig. B-1 suggest that sensitizing during glass casting should not be a problem.

The curves in Fig. B-1 are for unstressed material. Tensile stress shifts the curves to shorter times at temperature so that these curves carnot be used to accurately predict the time-temperature regime to

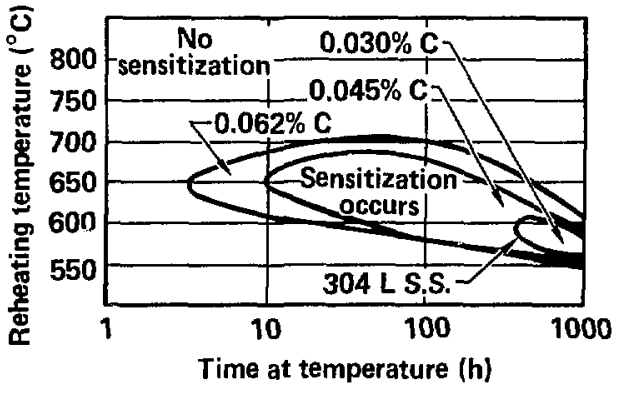

Figure B-1. Temperature-time-sensitization diagram for type 304 siainless steel (modified from Shrier, $1976^{\mathrm{B2}}$ ). 
cause sensitizing of 304L stainless steel. This question will have to be addressed as part of the materials testing program.

The low-temperature $\left(100\right.$ to $\left.300^{\circ} \mathrm{C}\right)$ time-temperature sensitizing curves for very long times (hundreds of years) are not known. The potential for sensitizing of $304 \mathrm{~L}$ in the repository environment will need to be assessed as part of the research and development program.

Other processes that might cause sensitizing of the steel are those associated with weldi "ID operations and residual stress from canister fabrication. Any stresses induced before using the canister as the receptacle for hot glass ran be removed by annealing the fabricated canister.

If sensitizing of the $304 \mathrm{l}$. is shown to occur during glass-casting operations, two alternatives are available: canisters could be overpacked with 304L that was not sensitized; or a different material (such as the stabilized grades of stainless steel 321 or 347), which is not susceptible to chromium carbide formation, coult be used for the canister.

If sensitizing is a problem because of the repository cooling history, the solution would be to use a material that would not be sensitized. Preliminary estimates suggest that use of 321 or 347 stabilized grades of steel would eliminate the sensitizing concern and would not introduce new difficulties. Some care needs to be taken when welding these grades of steel; preliminary assessnents indicate that the welding method proposed for the Defense Waste Processing liacility (DWPI) should be adequate.

Another possibility for minimizing sensitzation effects is use of a premium grade of $304 \mathrm{~L}$ with carefully controlled extra-low carbon content. As illustrated in Fig. B-1, lowering the carbon content pushes the time-temperature sensitization curves toward the right. The lower carbon content requires longer times before a sensitized structure occurs. In addition, the nitrogen content can be controlled to low levels, hecause this element also influences the sensitization behavior of stainless steels.

Pitting and crevice artack are a potential concern in the repository environment. These corrosion mechanisms come into play when a concentrated electrolyte comes in contact with a metal susceptible to pitting or crevice corrosion. Chloride concentrations that cause pitting and crevice attack on 304 stainless steel are shown in Fig. B.2. Once these mechanisms of corrosion are initiated, further rapid corrosion can occur at the site of initiation because of the local production of concentrated electrolyte solutions. While normal conditions in a repository sited in the unsaturated zone at Yucca Mountain will not produce solutions with high concentrations of electrolytes, there are some mechanisms by which localized attack by such solutions might occur. For example, water dripping from a fracture onto a hot canister might evaporate, leaving a residue of salts. An accumulation of small amounts of salts in a small area might later produce the potential for pitting or crevice corrosion at that site.

To address this concern, the metals testing program will evaluate the susceptibility of $304 \mathrm{~L}$ stainless steel to pitting and crevice corrosion under "over-stress" conditions of concentrated electrolyte solutions containing ions known to be present in water at the repository level. Particular emphasis will be placed on chloride and fluoride ions that are known to enhance pitting and crevice attack. Should 304L show a susceptibility to these motes of attack, the solution would be to use a material less prone to pitting and crevice corrosion. The $316 \mathrm{~L}$ and 317L grades of stainless steel would provide more resistance to pitting and crevice attack without introducing any known concerns in other areas.

Transgranular stress corrosion cracking can occur under the conditions aiready discussed for pitting and crevice corrosion, when the canister retains residual stress accumulated from the fabrication, welding, glass pouring, and cooling processes. In addition, the products of gamma radiolysis may accelerate this corrosion mechanism as well as pitting and crevice attack. Nickel additions to austenitic stainless steels ir $\cdots$ > rt greater resistance to transgranular stress corrosion cracking. Alloy 825 (Incoloy 825 ) is an example of a high-nickel stainless alloy that resists cracking in concentrated chloride-containing solutions." This alloy also contains molybdenum and titanium and is therefore more resistant to pitting, crevice, and intergranular corrosion than is $304 \mathrm{~L}$ in higher strength ionic solutions. However, alloy 825 is considerably more expensive than $304 \mathrm{~L}$. It would therefore merit use as a canister material only if our investigations showed that a combination of high residual stress and more aggressive chemical conditions did develop in the repository environment than we initially expected, and that the performance of $304 \mathrm{~L}$ in this circumstance was inadequate. If unstressed 304L shows adequate stress corrosion resistance, but stressed $304 \mathrm{~L}$ does not, then the obvious solution is to overpack the $304 \mathrm{~L}$ canister with a $304 \mathrm{~L}$ uverpack fabricated and welded by processes that minimize residual stress accumulation.

The final concern in connection with $304 \mathrm{~L}$ stainless steel is that of phase stability. While $304 \mathrm{~L}$ usually possesses an austenitic structure, this structure is metastable with respect to phase separation into ferritic 


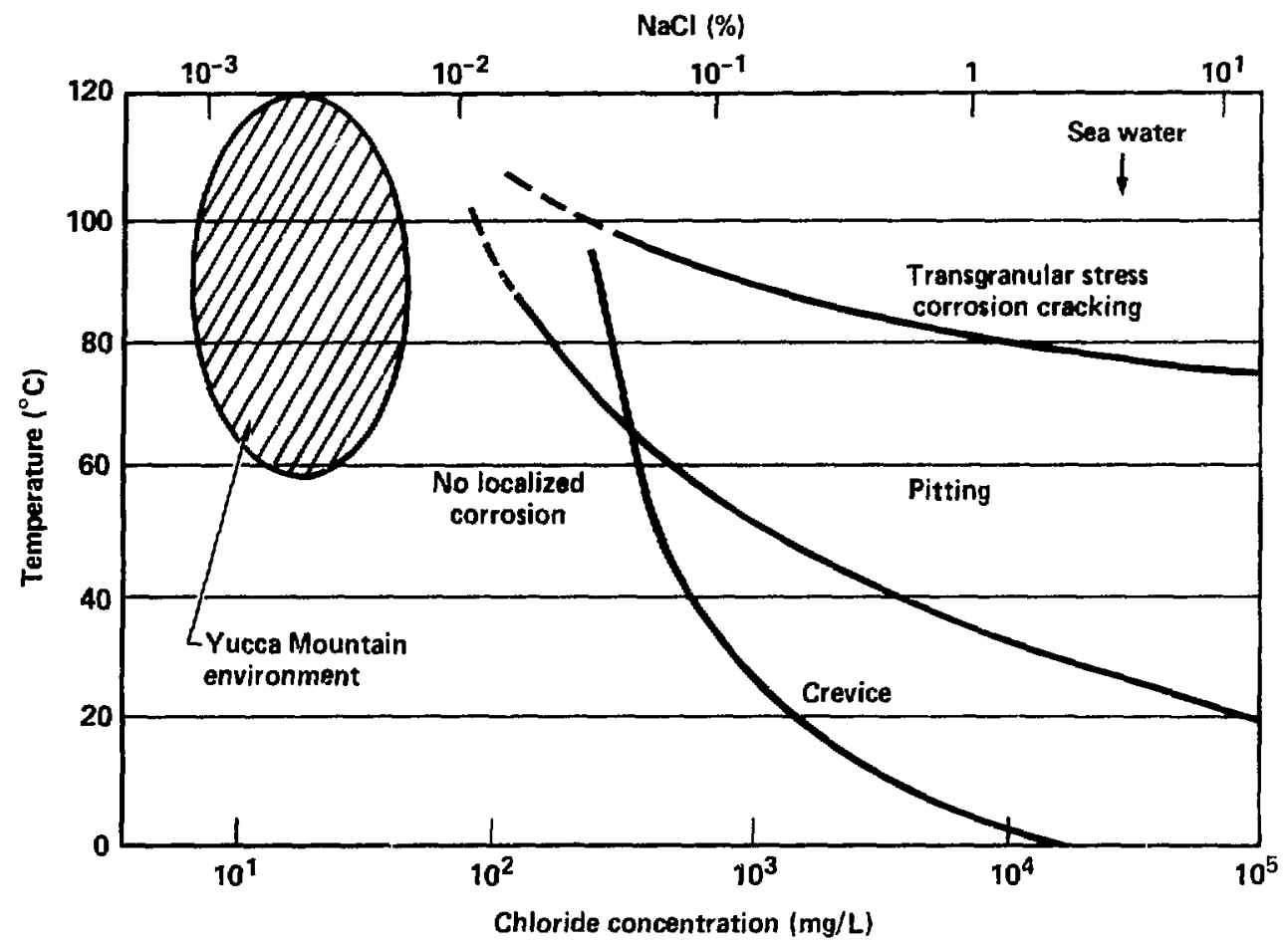

Figure B-2. Localized corrosion of type 304 stainless steel in water as a 'unction of temperature and chloride concentration (modified from Nuttall and Urbanic, 1981 ${ }^{16}$ ).

(body-centered cubic) and austenitic (face-centered cubic) phases of somewhat different compositions. This metastability is related to the overall alloy composition and is particularly sensitive to the carbon and nitrogen contents. By itself, a duplex ferrite-austenite structure is not necessarily detrimental to th. corrosion behavior. During welding and resolidification, some ferrite normally occurs in the fusion zone. This, in fact, is a desirable reaction because a low level of ferrite prevents hot cracking in the welded region, but a high level of ferrite may result in embrittlement. The ferrite phase has less fracture toughness than the corresponding austenitic phase, and the ferritic structure has a tendency over a long period of time to transform to a very brittle sigma phase. The usual practice is to keep the ferrite content between 5 and $10 \%$ in the weld zone. With regard to the phase stability of $304 \mathrm{~L}$ and other alternative austenitic stainless alloys previously discussed, an overall balance between the ferrite-stabilizing elements ( $\mathrm{Fe}, \mathrm{Cr}, \mathrm{Mo}, \mathrm{Ti}, \mathrm{Si}$, and $\mathrm{Nb}$ ) versus the austenite-stabilizing elements ( $\mathrm{Ni}, \mathrm{Mn}, \mathrm{Cu}, \mathrm{C}$, and $\mathrm{N}$ ) must be maintained. When an increase or decrease of one of these elements is specified to raise the resistance to a particular form of corrosion, an adjustment in the others is often required to preserve the desirable austenitic structure. In addition to the high fracture toughness of austenite, as opposed to that of ferrite, the austenitic structure is more resistant to hydrogen-provoked embrittlement. Hydrogen can enter metal lattice during aqueous corrosion. Radiolytic decomposition of water aiso produces hydrogen. Hydrogen embrittlement effects are associated with a strained metal lattice and represent another form of stress corr. ssion cracking. The testing program addresses this possible deleterious effect by use of stressed and welded coupons in the test matrix. If hydrogen embrittlement or loss of fracture toughness develops as a problem, remedies include tighter specifications of the canister alloy composition or use of a relatively unstressed overpack of $304 \mathrm{~L}$. 
The metals testing program is concerned with the reference material, AIS! 304I, stainless steel, and the three leading alternative materials, AISI 321L. AISI 316l., and Jncoloy 825. These alternative materials were nominated lecause of their improved resistance to particular forms of localized and stress-assieted corrosion. The alternatives are $316 \mathrm{~L}$. (more crevice and pitting corrosion resistant), 321 (more intergranular corrosion and intergranular stress corrosion resistant), and Incoloy 825 (more resistant to tranchranular stress corrosion, atso more resistant to pitting, crevice, and intergranular forms as well). Variations in the 3041 . composition, particularly toward premium grades with extra 1 /) carbon and low interstitial elements are included in the: test program matrix, too. Some other stainless steds may he teeted if time, resourcen, and the need exist. These primarily have compositions between 316l. and incoloy s25. They would be included in the text matrix if a concentrated electrolyte acenario were a realistic accursence: and if the halide son a concentration developed near the canister surface were much higher than that of the referenes 11.3 wats

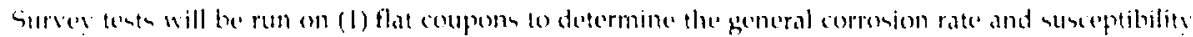

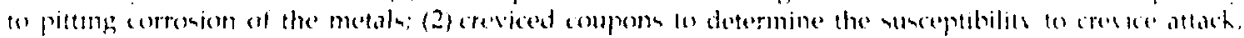

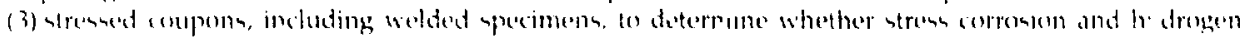

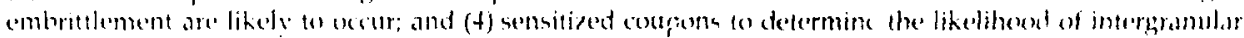

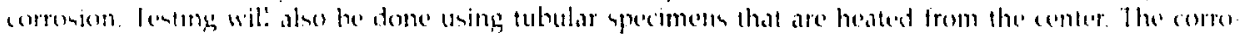

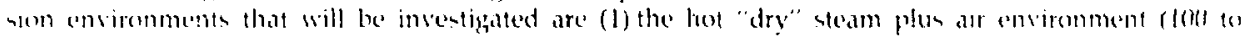

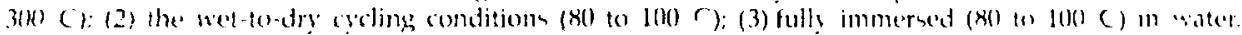
Ensirommens 2 and 3 will be mentigated with and withous the presence of gamma radialion in order to

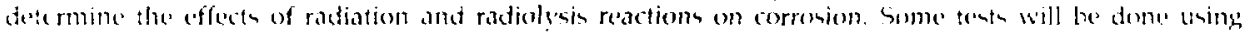

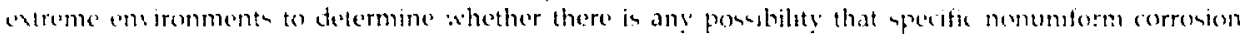

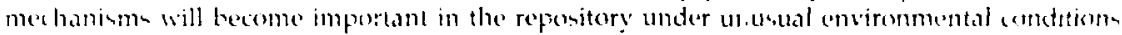

Jollowing completion of the survery testa, a metal will be chosen for une an the preluminare wale

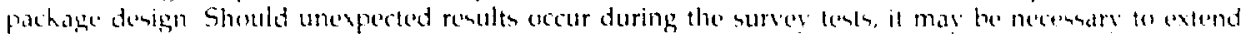
the lint af metals to solue particular problens. The metal selected for the preliminars denign, ance two altermativa materials, will then be subjected to intensive bong-lerm testing te confirm that performance in

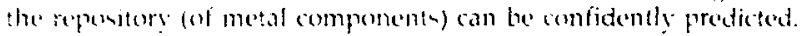

While the borchole linere discused as part of an alternative design for horisontal emplacement do

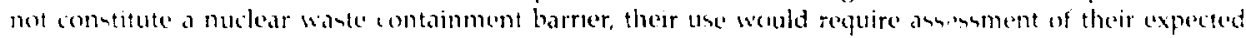

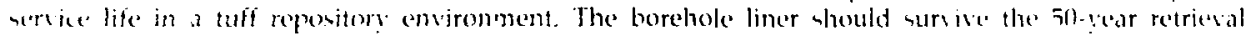
peried. The corrosion rate and corrosion attack pattern will therefore be determined on carbon steel under

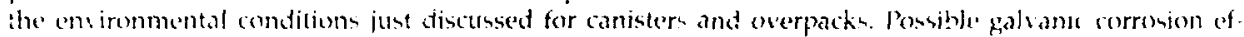
fectu befween the liner material and canister material will he dddresed.

An a final remark, it is recogmized that localized and stress-assisted forme of corrosion are the limiting

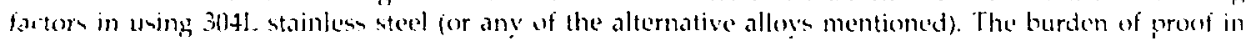
the metal barrier testing program is to show that the incidence of these types of occurrences balk to extremely low fored of probability under anticipated repesitory environmental condition. The ocourrence of locatized and stress-assisted forms of corrocion has a statistical distribution tor a given alloy/emironmental combinstion. Advanced testing procedures incorporate statistical factor in conducting the terts and analying results. Examples of these kinds of tests include use of extreme value stat: ich to ealuate long-term localize corrosion observations and use of fracture mechanics stress corrosim testing procedures to relate stress, the distribution of fabrication-induced flaws in metals, and the resulting crack-propagation rates. Details of these testing procedures are discussed by Ailor." The objective of this work is to reduce the uncertainty of test results to low levels, consistent with the eff art and expenditures in obtaining the results. Effort and money alone cannot buy experience, and while on $r$ experience with the proposed alloys is on the order of 50 years, the results of the metal testing wi'l be tracked with the available information on these alloys to obtain the most reasonable cxtrapolation possinle. Because stain. less steels were developed for their corrosion resistance, the corrosion ferformance information on these materials is abundant and very well-documented. 


\section{References}

B1. F. L. La Que and H. R. Copson, Corrosion Resistance of Metals and Alloys (Reinhold !ublishing Corp., New York, 1963).

B2 Corrosion, Vol. 1, L. L. Shreir, Ëd., isownes-Buiterworth, London, 1976.

B3. H. H. Uhlig, Corrosion and Corrosion Coni,ol (John Wiley \& Sons, Inc., New York, 1963).

B4. M. U. Fontana and N. D. Greene, Corrosion Engineering (McGraw-Hili Book Co., New York, 1977).

B5. John A. Sedricks, Corrosion of Stamiless Steels (John Wiley \& Sons, Inc., New York, 1979).

B6. Handook on Corrosion Trsting and Erahnation W. H. Ailor, Ed. (John Wiley \& Sons. Inc., New York, 1971). 


\section{Appendix C. Metals Data References}

C1. A Guide to Corrosion Resistance (Climax Molybdenum Co., technical brochure).

C2. Butre's Gitide de Slainless Slesl (Ryerson Steel Co., teclunical bulletin No. 13.2).

C3. Quick Relerence Ginde to High-Nickel Alloys (Huntington Alloys, technical bulletin).

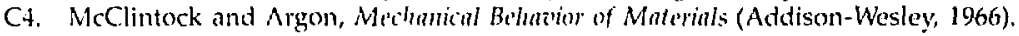

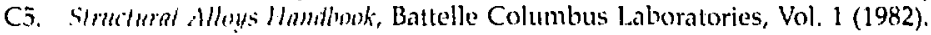

C6. Mulcrials ant Componculs in Fossil Energy Applicalions, DOE/FE-0053/41, Dec. 1, 1982 (Normalized and tempored $9 \mathrm{Cr}-1 \mathrm{Mol}$.

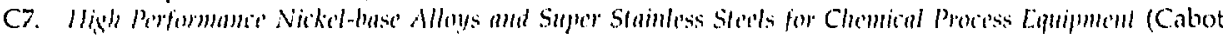
High Techmology Materials Division, lechnical report).

C8. Ti (Teledyne-Walh Chang Albany, OR, technical brochure).

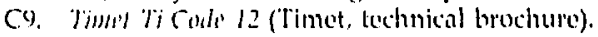

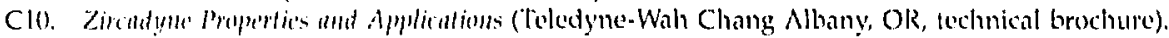

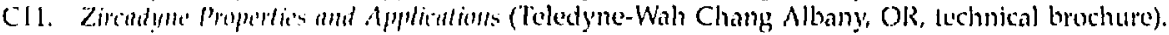

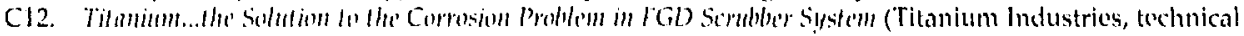
brochure).

C13. Bond if al, "Stainless Steds for Seawater Service," from Siamles Sithl 77, Climax Molybdenum Co.

C14. Arospace structural Mefuls ilmetheok (Mechanical Properties Data Center, U.S. Dept. of Defense, current revision).

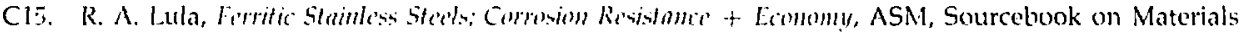
Selection, Vol. 1.

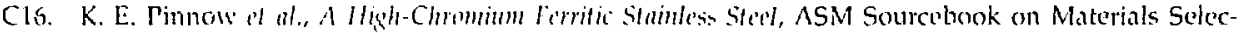
tion, Vol. 1.

C17. Hish-Temperalue Chomateristics of Stamless Steds (American lron and Steel Institute, technical report).

C18. Zirconimm Data like, Bulletin 5, "Zirconium Alloys for Nuclear Application, Grades 32 and 34." (Carborundum Metals Co.)

C19. AHS Wolimis llandhwh, section four.

C20. E. R. Parker, Matorials Dala Book (McGraw-Hill, 1967).

C21. ASME Pressure Vessel Code, Section VIll, Div 1.

C22. Hiph Stringlh, Low Alloy, Cr Sforls (ARMCO, lne. Bulletin I.H-308(3).

C23. Matrials Lnginnerins, 1981 Materials Selector.

C24. Current l.awrence Livermore National Laboratory Stores Catalog.

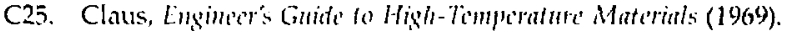

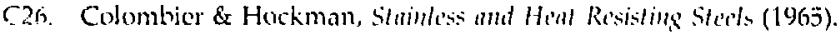

C27. I. Camphell, Low Tempertature Properties of Copper Alloys, CDA Technical Data Center Program, Battelle Memorial institute.

C28. Nuclear Test Cnginnering Diatsion De'sign Guite, current revision, Lawrence Livermore National Laboratory.

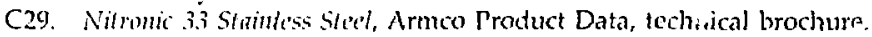

C30. Peckner \& Bernstein, Handhook of Stainless Strels (McGraw-Hill, 1977).

C31. Symposinm in Eleinled Temperoture Properfies of Alstenitic Stainless Steds, ASME, Miami Beach, FL, June 1974.

C32. Amoo Nitronic Stainless Sted and Ammo Nitromic 3.3 Stamless Sted, Armeo Stainless Steel Div. Publications, technical bulletins.

C33. R. H. Wright, "Toughness of Ferritic Stainless Steels," Toughmess of Forrilic Sininless Stecls, ASTM STP 706 (1980).

C34. C. R. Thonlas and R. L. Apps, "Weld Heat-Affected Zone Properties of AISI 409 Ferritic Stainless Steel," in Toughness of Ferritic Storls, ASTM STP 706 (1980).

C35. H. E. Deverell, "Toughness Properties of Vacuum Induction Method High-Chromium Ferritic Siainless Steels," in Toughmess of Fcritic Steds, ASTM STP 706 (1980). 
C36. Metz and Serno, "COD aild R-curve Analysis of Wide Plate Tests on Tonnage Tal i. iteel," in Fracture Toughness of Heroy-zoll Wolded Tomage Stecl, ASME MPC-5 (1977).

C37. Elerated Temperature Properties of Carbon Siccls, ASTM STP 180 (1955).

C38. Properties ami Selection of Matcrials, ASM Metals Handbook, 9th ed., Vol. 3, Metals Park, OH.

C39. Properties ant Solection of Matcrials, ASM Metals Handbook, 8th ed., Vol. 1, Metals Park, OH.

C40. Sumcebook w Stainless Steels, ASM, Metals Park, OH.

C41. Personal communication, Huntington Alloys, Glendale, CA, January 1983.

C42. Personal communication, Cabot Corp., Kokomo, IN, February 1983.

C43. Personal communication, Revere Copper Products, Inc, Rome, NY, January 1983.

C44. Fersonal communication, Timet Corp., lrvine, CA, January 1983.

C45. Personai communication, Ryerson Steel Corp., San Francisco, CA, January 1983.

C46. Fersonal communication, Teledyne-Wal: Chang Albany, OR, January 1983.

C47. Personal communication, Armco, Stainless Steel Division, Baitimore, MD, January 198j.

C48. Personal communication, Allegheny Ludlum Steel Corp, Pittsburgh, PA, February 1983.

C49. Personal communication, ESCO Corp., Eneryville, CA. February 1983.

C50. Personal communication, Capitol Pipe and Steel Products Co., Anaheim, CA, February 1983.

C51. Personal communication, Futura Metal Technology, Westlake Village, CA, February 1983.

C52. Tersonal communication, Jessop Steel Co., Washington, PA, February 1983.

C53. Returit linexpensize Tesls for Defermiming Fracture Toughmess, National Materials Advisory Board, National Academy of Sciences, Washington, DC, 1976.

C34. Faupel and Fisher, Engincering Design, A Sunthesis of Stress Analysis and Mnterials Engineering (John Wiley \& Sons, 1981).

C55. ASM Mitals Reforetric Book, American Society for Metals (ASM, Metals Park, OH, 1983), 2nd ed. 